\title{
Causes and Consequences of Invasive Plants in Wetlands: Opportunities, Opportunists, and Outcomes
}

\author{
Joy B. Zedler \\ Botany Department and Arboretum, University of Wisconsin-Madison, 430 Lincoln Drive, Madison, \\ WI 53706, USA \\ Suzanne Kercher \\ Botany Department, University of Wisconsin-Madison, 430 Lincoln Drive, Madison, WI 53706, USA
}

Referee: Professor Kristina A. Schierenbeck, Department of Biological Sciences, California State University, Chico, CA 95926, USA.

\begin{abstract}
Wetlands seem to be especially vulnerable to invasions. Even though $\leq 6 \%$ of the earth's land mass is wetland, $24 \%$ (8 of 33) of the world's most invasive plants are wetland species. Furthermore, many wetland invaders form monotypes, which alter habitat structure, lower biodiversity (both number and "quality" of species), change nutrient cycling and productivity (often increasing it), and modify food webs. Wetlands are landscape sinks, which accumulate debris, sediments, water, and nutrients, all of which facilitate invasions by creating canopy gaps or accelerating the growth of opportunistic plant species. These and other disturbances to wetlands, such as propagule influx, salt influx, and hydroperiod alteration, create opportunities that are well matched by wetland opportunists. No single hypothesis or plant attribute explains all wetland invasions, but the propensity for wetlands to become dominated by invasive monotypes is arguably an effect of the cumulative impacts associated with landscape sinks, including import of hydrophytes that exhibit efficient growth (high plant volume per unit biomass).
\end{abstract}

Keywords dominance, exotic species, landscape sink, monotype, Phalaris, Typha $x$ glauca

\section{INTRODUCTION}

Many wetland plants fit the definition of "invasive plants" as species or strains that rapidly increase their spatial distribution by expanding into native plant communities (Richardson et al., 2000). For example, southern Brazil's Alternanthera philoxeroides [Mart.] Griseb.; (alligator weed) arrived in Australia via ballast water in the 1940s. Within 60 years, it was considered a noxious weed throughout the continent because it roots in ponds, stream edges, floodplains, and wet croplands, and it expands vegetatively via hollow stems that facilitate flotation (Sainty et al., 1998). Also, its dense mats clog waterways, increase sedimentation, degrade pastures and crops, and enhance mosquito breed-

\footnotetext{
*Corresponding author: E-mail: jbzedler@ wisc.edu
}

ing (Sainty et al., 1998). Such invasive plants not only affect biodiversity and ecosystem functioning but also human use and enjoyment of wetlands.

The susceptibility of communities to invasion needs more attention (Prieur-Richard and Lavoral, 2000). Why are so many of the worst weeds invaders of wetlands? In Australia, little of the continent is wet, yet four of the most invasive weeds occur in wetlands (http://www.dlwc.nsw.gov.au/care/wetlands/ facts/paa/weeds/), and a dozen other wetland species are serious problems (G. Vivian-Smith, Weed Ecologist, Alan Fletcher Research Station, Department of Natural Resources, Mines \& Energy and CRC for Australian Weed Management, personal communication, 2004). Also, why do so many wetland plant invaders form monotypes rather than simply adding to native plant richness? We argue that wetlands are vulnerable to invasion in part because wetlands are landscape "sinks" that accumulate materials resulting from both terrestrial and wetland disturbances (excess water, nutrients, sediments, salts, heavy metals, other contaminants, and debris). Nearly every disturbance to an upland watershed causes some change downstream. For example, sediments that flow into wetlands transform topographically heterogeneous sites, such as tussocky meadows, into flat plains that support few plant species (Figure 1; Werner and Zedler, 2002; Larkin et al., In press). In addition, debris that floats downstream tends to accumulate in wetlands, where it can smother vegetation and create canopy gaps. We propose that the accumulation of materials in wetlands makes them particularly vulnerable to invasion, while at the same time supplying invaders with the resources they need to form monotypes.

Below we discuss a selection of invasive wetland plants and the wetlands they invade. Wetland invaders differ from many upland invaders in that (1) seeds are often dispersed via water$61 \%$ of the 441 wetland plant species listed in Middleton's (1999) Appendix 1 are known to be water dispersed; (2) whole plants and plant fragments can be dispersed via flotation; 


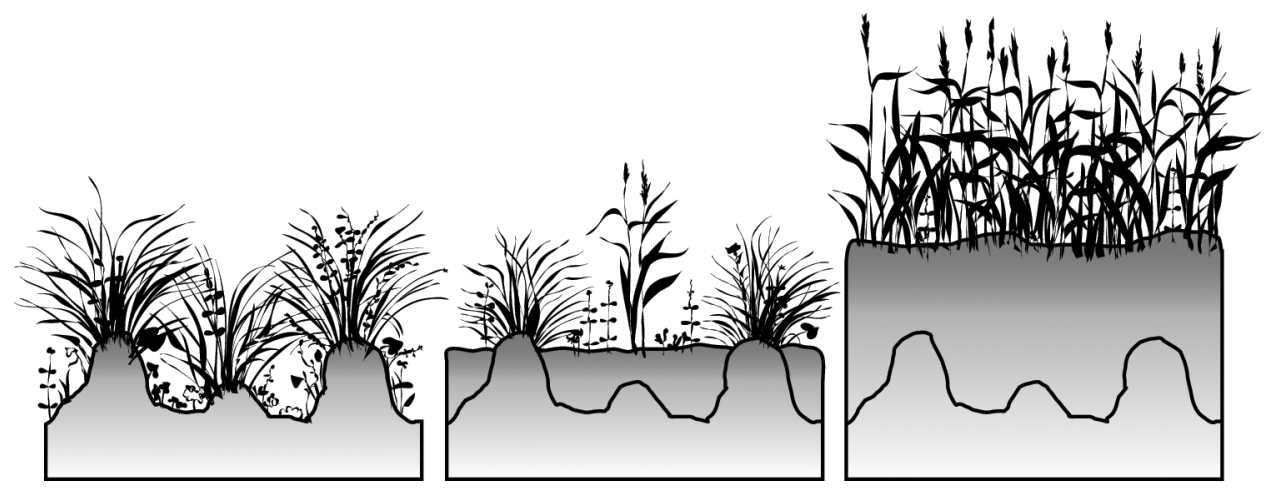

FIG. 1. Sedimentation flattens Wisconsin's topographically heterogeneous tussock sedge meadows; P. arundinacea becomes dominant (from Werner and Zedler, 2002; redrawn by K. Elliot).

(3) abundant aerenchyma (air tissue) protects belowground plant tissues from flooding and anoxic soils (Soukup et al., 2000), as well as allowing efficient use of carbon in above- and belowground growth; and (4) rapid nutrient uptake, allowing rapid growth.

Many invaded wetlands differ from invaded uplands in having, among other consequences of being landscape sinks, (1) through-flowing water, (2) frequent canopy gaps due to inflowing materials, (3) anoxic soils, and (4) ample nutrient influxes. While several hypotheses have been proposed to explain causes and consequences of invasions, we focus on five for which experimental data are available; these concern enemy release, broader tolerance, efficient use, hybrid vigor, and allelopathy. We then describe several "opportunity-opportunist matches" that help explain the tendency for lowlying wetlands to support invasions.

We confine our review to flowering plants. We exclude submersed and floating plants of aquatic (deepwater) habitats-not because deeper water wetlands are less threatened by invasives, but to limit the scope of our review. Thus, we consider emergent species that occupy permanent standing water, plants that occur in wet soils and soils with intermittent drying, and vegetation in transitions from wetland to upland. The following sections concern the following: invasion opportunities (factors that make wetlands vulnerable), opportunists (wetland invasive species and their attributes), current hypotheses of plant invasiveness (experimental evidence), opportunity-opportunist matches, outcomes (both negative and positive impacts) of invasives on wetland functions, the vulnerability of wetlands to invasions, and conclusions.

\section{OPPORTUNITIES: WHAT MAKES A WETLAND VULNERABLE TO INVASION?}

Various authors note that lowlying lands support high proportions of exotic species (e.g., Sobrino et al., 2002). But alien species abundance overall correlates with road density, suggesting that landscape position interacts with dispersal routes and disturbances to facilitate plant establishment. If dispersal routes are a strong factor, then it is understandable that riparian habitats are especially prone to invasion, as claimed by Stohlgren et al. (1998) and Tickner et al. (2001). Also, riparian wetlands are subject to flood pulses and mechanical disturbance, as well as inflows of materials from surface-water flows. Most wetlands occur in the low positions of the landscape, and many occur along river networks. Most are wetted by surface runoff in addition to rainfall and, in many cases, groundwater (Brinson, 1993). Hence, it is not surprising that Detenbeck et al. (1999) found a high number of exotics species in wetlands of the Great Lakes region in the U.S.

Wetlands fed by surface water from agricultural and urbanized watersheds tend to have many invasive species (Galatowitsch et al., 1999). Species richness is low and plants are of low "quality" (Kercher and Zedler, 2004). By quality we refer to coefficients of conservatism (CC) that have been assigned by expert botanists who distinguish high-quality species as those occurring in the least-disturbed remnants of native vegetation (Lopez and Fennessy, 2002; Mushet et al., 2002; Bernthal, 2003; Matthews, 2003). Such species score up to CC = 10 , while the weediest species are scored as $\mathrm{CC}=0-1$. Invasive species in Great Lakes wetlands tend to be accompanied by species with $\mathrm{CC}<5$ (C. Frieswyk, University of Wisconsin, personal communication).

Wetlands that are not fed primarily by surface water (e.g., slope wetlands, vernal pools, and high-altitude fens, bogs, and pools) have small watersheds and depend more on rainfall or groundwater than on surface-water runoff for their water supplies (e.g., Bedford and Godwin, 2003). These wetlands tend to be species rich and relatively free of invasive plants. Fens in the U.S. are noted for both their high species richness and high number of rare, threatened, and endangered species (Amon et al., 2002) - for animals as well as plants (Bedford and Godwin, 2003). Their high species richness is generally attributed to low nutrient concentrations in groundwater. The exceptions would be wetlands that receive large influxes of nitrogen from the atmosphere (Koerselman and Verhoeven, 1995).

Studies in Wisconsin show that wetlands with a history of hydrological disturbance (as evidenced by the presence of culverts 
and drainage ditches) show more widespread invasions than "reference sites" (high-diversity vegetation where indicators of hydrological disturbance are lacking; Kercher et al., In press). In comparing 12 sites ( 3 reference and 9 disturbed), we found an interaction between hydrological disturbance indicators and dominance by an invader that shows two patterns: (1) fewer species of native plants occur where the invader is present in plots in hydrologically disturbed wetlands, and (2) species of lower quality are mostly what is found in that situation (Figure 2). Hydrological disturbance affects nutrient availability, not just water levels, as nitrates are readily leached from oxidized soil during drainage and phosphorus is liberated upon rewetting (Olde Venterink et al., 2002). We concluded that disturbance facilitates wetland invasion and that the result is a decline in both the quantity and quality of native plant species.

The effect of nutrient inflows on wetland plant diversity was further investigated by Drexler and Bedford (2002) in New York fens. Eutrophication of one fen occurred by multiple pathwaysthe phosphorus and potassium loadings were traced to surface water from a nearby farm, while nitrogen loadings were enhanced by groundwater inflow from the same field. In both cases, diversity was reduced and a few plant species (e.g., Calamagrostis Canadensis [Michx.] Beauv. [bluejoint], Typha latifolia L. [broadleaf cattail]) produced monotypic stands.

Despite our emphasis on increased influxes as an invasioncausing disturbance, dewatering of landscapes also affects wetlands through drought-induced impacts on obligate wetlands

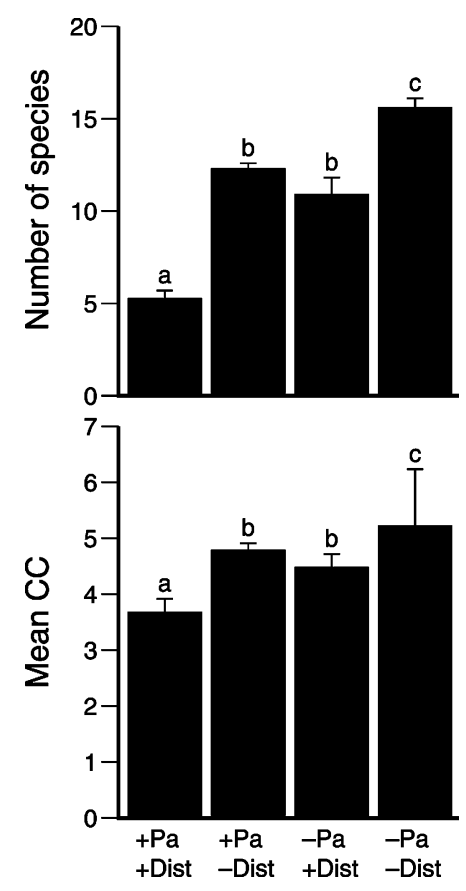

FIG. 2. Lower species richness (top graph shows mean number of species per $\mathrm{m}^{2}$ plot) and lower vegetation quality (bottom graph shows mean coefficient of conservatism per $\mathrm{m}^{2}$ plot; see text) are associated with sites that have indicators of hydrological disturbances. Plots came from 12 stands that had indicators of hydrological disturbance (+dist) or not (-dist) and either had P. arundinacea present $(+\mathrm{Pa})$ or did not $(-\mathrm{Pa})$ (From Kercher et al., In press). plants. Some invasives are particularly abundant where dams have reduced flood flows (e.g., Tamarix L. [tamarisk] spp.; Cox, 1999). Both increased and decreased runoff will alter wetland water regimes; the general point is that landscape sinks can be expected to respond to changes in the influx of materials.

\section{OPPORTUNISTS: WHICH SPECIES INVADE WETLANDS?}

Invasive wetland plants are often exotic (e.g., Lythrum salicaria L. [purple loosestrife]), but not always. Some are native (Typha domingensis Pers. [southern cattail] in the Florida Everglades), some are hybrids (e.g., Typha x glauca Godr., which is a cross between the native T. latifolia and the exotic T. angustifolia L. [narrowleaf cattail]; Galatowitsch et al., 1999), and some are exotic strains of a species that is native (e.g., Phragmites australis [Cav.] Trin. Ex Steud. [common reed] in the U.S.; Saltonstall, 2002). Still others are native strains that display invasiveness in response to environmental change. One population of Phragmites australis that invaded a wetland along Lake Superior was hypothesized to be exotic, but genetic analysis proved it to belong to the native strain (Lynch and Saltonstall, 2002). Finally, some wetland invasive species have uncertain origins. Phalaris arundinacea L. (reed canary grass) in the U.S. might be native, an exotic strain from Europe, or a hybrid strain (Galatowitsch et al., 1999).

We describe about two dozen species for which invasions into wetlands are treated in recent scientific publications (Table 1; naming as in USDA, 2004). Of these, Arundo donax L. (giant reed), Polygonum cuspidatum Sieb. \& Zucc. (Japanese knotweed $=$ Fallopia japonica $=$ Reynoutria japonica), Lythrum salicaria, Melaleuca quinquenervia (Cav.) Blake (punktree), Mimosa pigra L. (black mimosa), Schinus terebinthifolius Raddi (Brazilian peppertree), Spartina anglica C. E. Hubbard (common cordgrass), and Tamarix ramosissima Ledeb. (saltcedar) are among the 100 "Worst Invasive Alien Species" listed by the Global Invasive Species Database (LFT, 2004). The following descriptions focus on plant attributes and characteristics of the wetlands they invade. Of all the cases considered, the invasion ecology of Spartina alterniflora Loisel. (smooth cordgrass) in European coastal wetlands is probably the most researched and best understood.

\section{A. Grasses}

Spartina alterniflora (Poaceae) was accidentally introduced to England; by 1872, it had hybridized with the native S. maritima (M. A. Curtis) Fern. (small cordgrass) to form $S$. $x$ townsendii H. \& J. Groves, and it became fertile after chromosome doubling (forming S. anglica). Rapid spread is attributed to its fertile seeds and its ability to spread vegetatively $(30 \mathrm{~cm} / y e a r$ in Dovey Estuary) and the fact that it grows well on tidal mudflats that are too frequently inundated for native plants to colonize (Thompson, 1991). Other attributes noted are its ability to establish tussocks that accrete sediment, its $\mathrm{C}_{4}$ photosynthetic 
TABLE 1

Selected invasive wetland plants and seven of their attributes in invaded regions

\begin{tabular}{|c|c|c|c|c|c|c|c|}
\hline & $\begin{array}{c}\text { Forms } \\
\text { monotype? }\end{array}$ & Clonal? & $\begin{array}{l}\text { Viable } \\
\text { seed? }\end{array}$ & $\begin{array}{c}\text { Perennial } \\
\text { or annual? }\end{array}$ & $\begin{array}{l}\text { Hollow } \\
\text { stems? }\end{array}$ & Tall? & Salt tolerant? \\
\hline \multicolumn{8}{|l|}{ Grasses } \\
\hline Spartina anglica & Yes & Yes & Yes & $\mathrm{P}$ & Yes & $<2 \mathrm{~m}$ & Seawater \\
\hline Spartina densiflora & Yes & Yes & $?$ & $\mathrm{P}$ & Yes & $<2 \mathrm{~m}$ & Seawater \\
\hline Phragmites australis & Yes & Yes & No & $\mathrm{P}$ & Yes & $>2 \mathrm{~m}$ & Seawater \\
\hline Phalaris arundinacea & Yes & Yes & Copious & $\mathrm{P}$ & Yes & $\sim 2 \mathrm{~m}$ & \\
\hline Arundo donax & Yes & Yes & No & $\mathrm{P}$ & Yes & $>2 \mathrm{~m}$ & \\
\hline Polypogon monspeliensis & & No & Copious & $\mathrm{A}$ & Yes & $<1 \mathrm{~m}$ & Somewhat \\
\hline Parapholis incurva & & No & Copious & $\mathrm{A}$ & Yes & $<1 \mathrm{~m}$ & \\
\hline Agrostis avenacea & & & Copious & A & Yes & $<1 \mathrm{~m}$ & \\
\hline \multicolumn{8}{|l|}{ Graminoids } \\
\hline Typha x glauca & Yes & Yes & No & $\mathrm{P}$ & Yes & $>2 \mathrm{~m}$ & Somewhat \\
\hline Typha domingensis & Yes & Yes & Copious & $\mathrm{P}$ & Yes & $>2 \mathrm{~m}$ & Somewhat \\
\hline Typha orientalis & Yes & Yes & Copious & & Yes & $>2 \mathrm{~m}$ & Somewhat \\
\hline Juncus articulatus & & Yes & Yes & $\mathrm{P}$ & Yes & & \\
\hline \multicolumn{8}{|l|}{ Forbs } \\
\hline Polygonum cuspidatum & Yes & Yes & No & $\mathrm{P}$ & Yes & $>2 \mathrm{~m}$ & \\
\hline Lythrum salicaria & & & Copious & $\mathrm{P}$ & Yes? & $\sim 2 \mathrm{~m}$ & \\
\hline Alternanthera philoxeroides & Yes & Yes & $?$ & $\mathrm{P}$ & Yes & $<1 \mathrm{~m}$ & \\
\hline Impatiens glandulifera & Yes & No & Yes & A & Yes? & $2.5 \mathrm{~m}$ & \\
\hline \multicolumn{8}{|l|}{ Shrubs and trees } \\
\hline Mimosa pigra & & & & $\mathrm{P}$ & No & $4-5 \mathrm{~m}$ & \\
\hline Melaleuca quinquinervia & Yes & & Copious & $\mathrm{P}$ & No & $>2 \mathrm{~m}$ & \\
\hline Schinus terebinthifolius & Yes & & Copious & $\mathrm{P}$ & No & $>2 \mathrm{~m}$ & \\
\hline Tamarix ramosissima & Yes & & Copious & $\mathrm{P}$ & No & $>2 \mathrm{~m}$ & Up to $1 / 2$ seawater \\
\hline Triadica sebifera & Yes & & Copious & $\mathrm{P}$ & & $>2 \mathrm{~m}$ & Somewhat \\
\hline
\end{tabular}

pathway, salt tolerance, allopolyploid vigor, and morphological variation (both phenotypic and genetic; Thompson, 1991).

S. alterniflora was also introduced to the U.S. Pacific Northwest Coast, in this case deliberately to stabilize dredge spoils. It has recently become highly invasive in three states, Washington, Oregon, and California's San Francisco Bay (Ayres et al., 1999; CSCC, 2004). It is now problematic in over 8,093 ha along the coast of Washington (Hedge et al., 2003). As in Europe, it occupies habitats lower than native vegetation, but it also occupies higher elevations, with a vertical intertidal range of $\sim 1 \mathrm{~m}$. Oyster growers and bird watchers both complain that it has eliminated valuable mudflat habitat. In San Francisco Bay, it grows upslope into native stands of $S$. foliosa (Callaway and Josselyn, 1992), with which it hybridizes (Ayres et al., 1999; Hedge et al., 2003). Vigorous hybrids of S. alterniflora and S. foliosa threaten to displace the native $S$. foliosa throughout San Francisco Bay (Daehler and Strong, 1997; Ayres et al., 1999).

In Humboldt Bay, California, Spartina densiflora (denseflower cordgrass; Poaceae) occurs in all 393 ha of salt marsh, where it was long considered to be a tussock-forming variant of S. foliosa. Chromosome and morphological comparison showed it to be an exotic from South America (Spicher and Josselyn,
1985) that was likely introduced with ballast water from ships involved in the timber trade. The species is also expanding in San Francisco Bay (Callaway and Josselyn, 1992; CSCC, 2004), where it was planted and where it occupies an elevation that is broader than the native $S$. foliosa. While it is a prolific seed producer ( 2000 viable seeds/plant), germination is limited to episodes of lowered salinity; hence, most spread is vegetative (Kittelson and Boyd, 1997).

Phragmites australis (Poaceae) has a nearly global distribution, but recent genetic work shows the USA invasive strain to differ from more natural and noninvasive populations (Saltonstall, 2002). Along the USA Atlantic Coast, this species has greatly increased its distribution into the upper reaches of salt marshes (invading Spartina alterniflora), where it was considered a less desirable species for wildlife and fish. Recent research, summarized in a special issue of Estuaries (Vol. 26, No. 2B) somewhat rebuts the claim that $P$. australis fails to support native fish and wildlife. Nevertheless, many salt marsh restoration projects have as a principal goal the replacement of $P$. australis with $S$. alterniflora. Although plants are sterile, the fragments of rhizome and stems can disperse and expand vegetatively (Bart and Hartman, 2003). The invasive strain is 
highly productive (Farnsworth and Meyerson, 2003). It is drawing notice throughout its temperate-region distribution in the U.S. because its salt tolerance allows it to expand along highways where salt is used to melt snow and ice (Galatowitsch et al., 1999).

Phalaris arundinacea (Poaceae) is invasive across its temperate-region range in North America (Galatowitsch et al., 1999; Paveglio and Kilbride, 2000). In Wisconsin alone, it dominates ( $>80 \%$ cover) more than 40,000 ha of wetlands (Bernthal and Willis, 2004). In addition to seed and rhizome reproduction, it forms roots in the axils of its branches, and branches and node-bearing plant fragments can both establish new plants. European strains were introduced to North America (and are still used) for forage and streambank erosion control. Few species remain where this plant dominates (Kercher et al., In press). Wetlands with enhanced runoff, sediments, and nutrients are particularly vulnerable to invasion by this species (Kercher and Zedler, 2004).

Arundo donax (Poaceae) was introduced from the Mediterranean and elsewhere in the Old World to many regions, including Mexico, the Caribbean, and California for use in thatching adobe buildings of the Spanish missions. It occurs widely throughout the southern U.S. (USDA, 2004) and has recently expanded its distribution along coastal California, especially in riparian wetlands (J. Zedler, personal observation). Plants resemble Phragmites australis but grow much taller (up to $10 \mathrm{~m}$ ). It does not produce viable seed, but it reproduces vegetatively by both rhizomes and node-bearing plant fragments (Dudley, 2000).

Polypogon monspeliensis (L.) Desf. (annual rabbitsfoot grass; Poaceae) is an annual grass that expands episodically in high salt marshes of southern California. When rainfall is sufficient to lower soil salinities, the numerous seeds of this species germinate and establish seedlings (Callaway and Zedler, 1998; Kuhn and Zedler, 1997). Since annual grasses are not a natural component of this community, its presence is obvious during the dry summer, when its pale dead stems contrast with evergreen halophytes. In experiments, P. monspeliensis produced higher biomass than a native associate, Salicornia virginica (Callaway and Zedler, 1998).

Parapholis incurva (L.) C. E. Hubbard (curved sicklegrass; Poaceae) is another annual species that occurs in coastal states and, in southern California, invades the high salt marsh of coastal wetlands. At Tijuana Estuary, the plants co-occur with an endangered species, Cordylanthus maritimus Nutt. ex Benth. ssp. maritimus (saltmarsh bird's-beak), which is a hemiparasite. Because the hemiparasite is an annual, and because it must tap into roots of a perennial-plant host in order to obtain sufficient water and nutrients to live long enough to produce seeds, $P$. incurva can interfere with the endangered species' survival. Fellows (1999) showed that $C$. maritimus can attach to the roots of $P$. incurva but that this host dies before the endangered plant can reproduce. The endangered species is "tricked" by the invasive host, like a habitat sink. At Tijuana Estuary, where the endangered plant persists, up to $92 \%$ of seedlings were exotics, with $P$. incurva the most abundant (Noe and Zedler, 2001).
Agrostis avenacea J. F. Gmel (Pacific bentgrass; Poaceae) is an Australian annual and facultative perennial grass that is becoming a strong threat to biodiversity by rapidly invading vernal pools in southern California (Zedler and Black, In review). These pools support several rare and endangered plants and animals; hence, dominance by an invasive threatens an entire rare ecosystem. Over $90 \%$ of historical vernal pools of southern California have been urbanized, as the depressions occur within flat mesas near the coast, which are prime sites for housing developments.

\section{B. Graminoids}

Typha $x$ glauca (Typhaceae), a hybrid between the native T. latifolia and the exotic T. angustifolia, is an aggressive invader of disturbed wetlands across much of the eastern U.S. (Galatowitsch et al., 1999). F1 plants are sterile, but the parents are abundant and widely sympatric, and offspring expand aggressively via rhizomes. Hybrids are common wherever both parents occur (Galen Smith, University of Wisconsin, personal communication, 2004). This invader responds more rapidly to nutrient addition than sedge meadow vegetation (Woo and Zedler, 2002), and it crowds out many native species, leaving only those of low quality (thus having a monotype form of dominance, cf. C. Frieswyk, University of Wisconsin, personal communication). Great Lakes wetlands have an abundance of this invader, especially where watersheds are urbanized, such as along Lake Erie and within Lake Michigan's Green Bay (Frieswyk et al., In review).

Typha domingensis (Typhaceae) has greatly expanded its distribution in the Florida Everglades in response to increased phosphorus runoff from sugar cane fields (Miao and Sklar, 1998). Its distribution into native Cladium jamaicense Crantz (Jamaica swamp sawgrass) vegetation follows canals that drain agricultural lands; from there it expands vegetatively into the native vegetation. T. domingensis also tends to be invasive in southern California, where its expansion into saline wetlands is catalyzed by freshwater inflows (Beare and Zedler, 1987). Once established (during low-salinity windows), it persists vegetatively.

Typha orientalis C. Presl (cumbungi; Typhaceae) is native to eastern but not western Australia. Near Perth, this species moves into Juncus krausii marshes where soil salinity is reduced by urban runoff (Zedler et al., 1990). Gaps in the canopy along drainage ditches would thus allow seedlings to establish, and rhizome growth would allow penetration into native vegetation (Zedler et al., 1990).

Juncus articulatus L. (jointleaf rush; Juncaceae) is native to the U.S. and Europe and invasive in Australian temporary wetlands, creeks, and drainage channels, where it germinates from long-lived seed banks and expands via rhizomes (Smith and Brock, 1998). J. articulatus produced many more tillers and much higher biomass than a native associate, Glyceria australis, in experiments by Smith and Brock (1996).

Another graminoid to watch is Juncus acutus L. (spiny rush; Juncaceae), which is common in coastal wetlands of the Mediterranean Sea and is native (but rare) in southern California coastal 
wetlands. This species appears to be increasingly weedy in western Australia (J. Zedler, personal observation), especially in wet places where agricultural activities cause secondary salinization of soil (Williams, 2001).

\section{Forbs}

Polygonum cuspidatum (Polygonaceae) is native to eastern Asia but it is now widespread in central and northern Europe and it occurs in most of the U.S. It is most invasive in riparian wetlands (Brock et al., 1995; Sukopp and Starfinger, 1995). Plants are tall, rhizomatous, herbaceous to shrubby, persistent, and difficult to control (Seiger and Merchant, 1997). Sometimes called a "giant herb," it can grow to $4.5 \mathrm{~m}$ tall and accumulate biomass of $200 \mathrm{t} / \mathrm{ha}$ (Sukopp and Starfinger, 1995). Because seeds of this species produced outside Japan are not viable, reproduction is largely by rhizomes or rhizome fragments (Bailey et al., 1995) and stem fragments (Brock et al., 1995). Dispersal occurs via flowing water (Sukopp and Starfinger, 1995). In the U.S. Pacific Northwest, Toney et al. (1998) identified this plant as the most rapidly spreading invader, and in Switzerland Weber (2000) listed it as a species of "high concern." In the British Isles, $P$. cuspidatum crosses with native species to form invasive hybrids that produce hybrid seeds (Bailey et al., 1995), suggesting increasing invasiveness.

Lythrum salicaria (Lythraceae) is a subshrub from Europe that was introduced to North America for its purple flowers; however, it probably also arrived accidentally by dispersal of its copious small seeds (Galatowitsch et al., 1999). It is now highly invasive along riverbanks and in wetlands across temperate North America (Galatowitsch et al., 1999; Lindgren, 2003), where it is a competitive dominant (Hagert, 2004) that forms monotypes (Thompson et al., 1987). In Manitoba, infestations increased 13-fold between 1991 and 2001, with over 4000 ha infested in the central part of the province. Blossey et al. (2001) cite multiple impacts of this species on ecosystem functioning (cf. section VI) and on the native L. elatum, which can have reduced pollination and lower seed production in the presence of L. salicaria.

Alternanthera philoxeroides (Amaranthaceae) is a clonal forb that is native to South America but highly invasive in California and Florida waterways and in Australia (Sainty et al., 1998). It was deliberately introduced to Australia as a vegetable and medicinal herb. Stems are long, branched and hollow; dispersal occurs as fragments, as reproduction is entirely vegetative. It establishes readily from stem nodes and rhizomes, especially along riverbanks; plants can break away from the parent clone and persist as free-floating mats (Sainty et al., 1998).

Impatiens glandulifera Royle (ornamental jewelweed; Balsaminaceae $)$ is a tall $(\sim 2.5 \mathrm{~m})$ annual forb from Himalaya that forms monospecific stands along river banks and other moist habitats in UK and Europe (Beerling and Perrins, 1993; Tickner et al., 2001). Beerling and Perrins (1993) describe its distribution in UK as widespread and among the top 20 alien problems. While each plant produces only 4 to 16 seeds per flower, a square meter with 20 plants produces 700 to 800 seeds, which are dispersed via explosive dehiscence (up to $4 \mathrm{~m}$ from the plant); in the following year, seeds germinate synchronously to produce a monotype (Beerling and Perrins, 1993). Adventitious roots help it remain upright. Extrapolating from data on water content of stems (91\%) and tall growth form (Beerling and Perrins, 1993), which are shared by our Wisconsin congener, I. capensis Meerb. (jewelweed), we speculate that this species has "efficient growth" (section IV) via hollow stems. I. capensis behaves as an invasive in Wisconsin, although its ability to dominate appears to be moisture and competition limited (personal observation).

Other notable forbs that invade wetlands are Heracleum mantegazzianum Sommier \& Levier (giant hogweed, Apiaceae) - a 5-m tall perennial (rhizomatous) plant from the Caucasus that is invasive in a few northern states in the U.S. of great concern in riparian areas of UK (Tickner et al., 2001), and expanding along streambanks in Ireland (Caffrey, 2001)_and Lepidium latifolium L. (broadleaved pepperweed, Brassicaceae), which is expanding rapidly in northern California (Howald, 2000). Like Pastinaca sativa L. (wild parsnip) in the U.S., H. mantegazzanianum produces phototoxic chemicals that sensitize the skin where people touch the plants.

\section{Shrubs and Trees}

Mimosa pigra (Mimosaceae), from Central and South America, is a highly invasive shrub in Australia, Southeast Asia, and Florida, where it grows to $6 \mathrm{~m}$ in shrubby, prickly thickets (Langeland and Craddock Burks, 2000). Introduced as a curiosity plant, its seeds are dispersed in annual floodwaters, and its establishment is facilitated by grazing disturbances on floodplains (Zedler and Rea, 1998). Infestations covering $800 \mathrm{~km}^{2}$ are described for Australia (Langeland and Craddock Burks, 2000). In Northern Territory, it germinates en masse on floodplains and grows rapidly to reproductive maturity (Rea, 1998).

Melaleuca quinquenervia (Myrtaceae) was planted as an ornamental in Florida and now infests over 200,000 ha of south Florida wetlands, of which 10,000 to 20,000 ha are virtual monocultures (Turner et al., 1998). The Everglades "river of grass" is being transformed into wooded swamps dominated by this fire-adapted tree. Fire not only leads to resprouting, it also releases copious seeds ( $\sim 20$ million per tree) that readily establish seedlings on the fertile ash bed. The species invades along canal banks and roads, as well as in cypress swamps, pine flatwoods, bottomland forests, and mangrove swamps (Turner et al., 1998). It is Florida's greatest invasive threat in wetlands, causing up to $80 \%$ loss in biodiversity (Turner et al., 1998). The species matures rapidly and can produce up to 5 seed crops per year (Turner et al., 1998). In Puerto Rico, it forms monotypes in abandoned agricultural fields where both flooding and fire occur; this combination of disturbances is not tolerated by any native tree (Lugo, 2004).

Schinus terebinthifolius (Anacardiaceae) is a small tree $(10 \mathrm{~m}$ tall) that forms densely intertwined braches (thickets). It is native to South America but was introduced as an ornamental to the 
southern U.S. It is highly invasive in Texas and Florida wetlands. In the Florida Everglades areas that were rock plowed (porous limestone substrate crushed to allow cultivation), nutrients (especially phosphorus) were released and a monoculture of this tree developed (Simberloff et al., 1997; Li and Norland, 2001). Concentrations of phosphorus in leaves were 5 times those of the native sawgrass (Simberloff off et al., 1997; Li and Norland, 2001). While trees could be bulldozed and burned, the complete removal of nutrient-rich soil was necessary to prevent their recolonization (Dalrymple et al., 2003).

Tamarix ramosissima (Tamaricaceae) and its congeners are native trees in Europe and Asia and highly invasive in Texas and the western U.S. (Stevens, 1989; Cox, 1999; Lesica and Miles, 2001; Ellis et al., 2002) and Australia. This tree colonizes open riparian wetlands and floodplains, especially where dams have reduced flood frequency (Ellis et al., 2002; Sher et al., 2002). It grows rapidly to $4 \mathrm{~m}$ in the first year of growth. Its abundant, wind-dispersed seeds germinate upon wetting, including in soils that are saline at the surface, and seedlings rapidly grow roots that reach the water table (Lesica and Miles, 2001). Branches that are buried by flood-borne sediments grow into new shoots, forming clones (Lesica and Miles, 2001); it also forms adventitious roots. Its ability to accrete sediments is seen as a cause of increased flooding, and its high water use and evapotransiration rates have high economic impacts throughout its arid-region distribution (Zavaleta, 2000). Cox (1999) reports that 90\% of New Mexico's bosque (woodland) is heavily modified, and remnants are dominated by three species of Tamarix, along with many other invasive species.

Triadica sebifera (L.) Small (= Sapium sebiferum; tallowtree; Euphorbiaceae) from eastern Asia is expanding its already widespread distribution in the southeastern U.S., where it occurs in wetlands and moist uplands (USDA, 2004). This tree grows rapidly and forms monotypes, crowding out native plants. In Louisiana and Texas, it replaces imperiled coastal prairie (Barrilleaux and Grace, 2000; Rogers and Siemann, 2003). It also replaces forested wetlands following hurricanes (Conner et al., 2002). The species is considered naturalized along the coastal plain from Texas to North Carolina (Conner et al., 2002).

Another tree of concern is Acer negundo L. (boxelder, Aceraceae) from North America, as it is increasingly abundant in Wisconsin's riparian woodlands (J. Zedler, personal observation) and invading riparian habitats in southwestern France (Tabacchi and Planty-Tabacchi, 2003).

\section{WHY ARE SOME WETLAND PLANTS HIGHLY INVASIVE?}

Several hypotheses have been proposed to explain invasiveness in plants in general (Rejmanek, 2000), and the ability to predict species that might become pests has improved (Daehler et al., 2004). For P. arundinacea, any one of the following traits might confer invasiveness: some strains were bred for productivity; it is wind pollinated; it is highly productive of seeds; its seeds germinate within six days of wetting; germination rates are high upon wetting, but some seeds remain dormant and can germinate after storage for 3 years; new populations can established from dispersed seeds, whole plants, and branch fragments; it produces rhizomes with numerous buds; new ramets benefit from a clonal subsidy; plants can grow into tussocks as well as swards; it grows over a longer season than most native plants in Wisconsin; it can make use of nutrient pulses; it has a broad ecological niche; it displays morphological plasticity (e.g., branching upright when stems fall); its leaves and stems show little evidence of herbivory in Wisconsin; and its hollow stems allow great height growth per biomass investment. Indeed, all of the species we discuss (section III) possess multiple characteristics that might be what makes them formidable invaders. It is the systematic testing of alternatives that advances understanding.

In a review of 150 studies, Levine et al. (2003) found that fewer than 5\% tested the processes responsible for plant invasions. We focus on five that have been tested experimentally, or are testable, using wetland species: release from natural enemies, broad tolerance limits or tolerance of harsh conditions, more efficient or complete use of resources, hybrid vigor, and allelopathy. This list is not exhaustive, nor are the hypotheses of invasiveness exclusive of one another.

\section{A. The Enemy Release Hypothesis}

This hypothesis predicts that exotic species are released from pathogens when introduced into new areas and that a relatively greater release from pathogens correlates with increased invasiveness. Support for this hypothesis comes from Klironomos (2002) and Mitchell and Power (2003). Using Lythrum salicaria as the test species, however, Willis and Thomas (1999) found no evidence that a plant with fewer enemies allocated fewer resources to defense and increased its competitive ability. In contrast, Siemann and Rogers (2001) found that invasive genotypes of Triadica sebifera from recently colonized areas in North America had the strongest growth but poorly defended leaves, while native Asian genotypes had the weakest growth and well-defended leaves, and genotypes from its original introduction site in North America were intermediate in both growth and leaf defense. Rogers and Siemann (2003) also found T. sebifera to be herbivore tolerant. While most experimental tests of the predator/pathogen release hypothesis have focused on agricultural and upland species, wetland species may have different susceptibilities to pathogenic viruses, fungi, and herbivores. The screening of potential biocontrol agents is inherently an experimental test of the enemy release hypothesis, and several studies report reductions in the productivity and vigor of invasive wetland plants upon exposure to host-specific biocontrol agents (e.g., for Lythrum salicaria in North America, Blossey et al., 1994a, 1994b; Voegtlin, 1995; Nyvall and $\mathrm{Hu}, 1997$; for Spartina alterniflora in Washington, U.S. Grevstad et al., 2003).

\section{B. The Broader Tolerance Hypothesis}

This hypothesis predicts that invasive species have broader tolerance limits, tolerate extreme environmental conditions 
better than noninvasive species, or both. Goodwin et al. (1999) identified 165 congeneric pairs of European plant species; each pair consisted of one species that has invaded North America and one species that has not. Upon comparing life form, stem height, flowering period, and European range as predictors in a logistic regression model, only the latter was reliable, predicting invasiveness correctly $70 \%$ of the time. Greater tolerance would favor wetland plant invasions where hydrological shifts occur (Newman et al., 1996; Kercher and Zedler, In review).

Several studies have tested growth responses under different hydroperiods. Experiments with invasive cattail Typha domingensis and the native Everglades species Cladium jamaicense and Eleocharis interstincta (Vahl) Roemer \& J. A. Schultes (knotted spikerush) showed that only T. domingensis responded positively to increased water depth $(15,30$, and $60 \mathrm{~cm})$ by increasing biomass as much as 60\% (Newman et al., 1996). Greater flood tolerance in $T$. domingensis over the native species may be due to higher levels of aerenchyma in the former (Chabbi et al., 2000). Likewise, P. arundinacea had higher biomass and higher aerenchyma than 16 other taxa tested across four hydroperiods (Kercher and Zedler, In review). Similarly, Spartina anglica exhibited enhanced exchange of $\mathrm{O}_{2}$ and $\mathrm{H}_{2} \mathrm{~S}$ between the rhizosphere and atmosphere compared to that of its native North American congener Spartina alterniflora (Lee, 2003). Evidence against the hypothesis of greater tolerance to harsh conditions comes from a study of six species in the family Lythraceae, including Lythrum salicaria. All six species had very similar responses to flooding (Lempe et al., 2001).

Hydrological shifts also include changes in salinity, sedimentation, and pollutant inflows. Lowered salinity increased invasion by Polypogon monspeliensis into salt marshes (Callaway and Zedler, 1998), sedimentation increased $P$. arundinacea invasions into sedge meadows (Werner and Zedler, 2002), and Lythrum salicaria was able to grow even with lead levels as high as $2000 \mathrm{mg}$ per liter (Uveges et al., 2002). Further tests of the greater-tolerance hypothesis are warranted, since shifts in hydrology involve multiple environmental factors and potential interactions.

\section{The Efficient Use Hypothesis}

This hypothes states that invasive species make more efficient or complete use of light and nutrient resources than noninvasive species. Several experimental studies have demonstrated relatively greater growth responses in invasive species to increases in light, nutrients, or both. To facilitate light capture, invasive species may have one or more of the following: an extended growing season, morphological plasticity or a fixed but advantageous architecture, and higher photosynthetic rates. These traits have been reported to occur in invasive species in uplands (e.g., Grotkopp et al., 2002; Morris et al., 2002; Stratton and Goldstein, 2001) as well as wetlands (e.g., for phenology and growth form of $P$. cuspidatum along alpine rivers Marigo and Patou, 1998; for phenology of Rhamnus cathartica Harrington et al., 1989).
As with light, some invasive plants have a greater capacity to utilize nutrients to promote their expansion at the expense of noninvasive species. For example, Newman et al. (1996) found that nutrient enrichment increased growth of $T$. domingensis but not Everglades marsh natives. Similarly, Woo and Zedler (2002) found increased Typha x glauca biomass but no change in native Carex L. spp. biomass due to nutrient addition. Green and Galatowitsch (2002) showed increases in P. arundinacea biomass and suppression of native wet meadow species with high levels of nitrate-N addition, and Kercher and Zedler (2004) found that nutrient enrichment caused a greater relative increase in $P$. arundinacea than in native wet prairie species.

Kercher and Zedler (2004) tested a related hypothesis concerning fluctuating resources (Davis et al., 2000), which states that invasion occurs when the system has an excess of resources, either through reduced uptake by resident species or increased supply. P. arundinacea became more invasive in a wet prairie assemblage as nutrients, sediment, and flooding increased (3 levels of each factor, full-factorial design). In one growing season, factors synergized to produce a monotype of $P$. arundinacea in 3 of 28 treatments (Kercher and Zedler, 2004).

\section{The Hybrid Vigor Hypothesis}

This hypothesis focuses on invaders with different species as parents. Ellstrand and Schierenbeck (2000) present evidence that hybridization is a major and underappreciated cause of invasiveness. They documented 28 examples supported by strong evidence that hybridization events preceded invasiveness, including the wetland taxa Spartina anglica, Lythrum salicaria $x$ L. alatum Pursh (winged lythrum), and Spartina alterniflora $x S$. foliosa Trin. (California cordgrass) in North America (see also Ainouche et al., 2004 re. Spartina hybrids). Typha $x$ glauca is another example of a hybrid invasive wetland plant (Galatowitsch et al., 1999). Highly invasive Tamarix spp have also been shown to be novel hybrids of European genotypes that were geographically isolated in Eurasia (Gaskin and Schaal, 2003; Schaal, et al., 2003). Experimental work on Polygonum cuspidatum in the Czech Republic has shown that hybrids that are genetically intermediate between the parents have greater regeneration rates (Pysek et al., 2003).

\section{E. The Allelopathy Hypothesis}

This hypothesis predicts that some plants become invasive monotypes through the release of biochemical toxins that inhibit the growth and germination of species in the area of introduction, as those species have not had a chance to evolve resistance to the phytotoxins. To date, the most convincing example is a new study on Centaurea maculosa, an invasive plant of grasslands (Bais et al., 2003). Although the case for allelopathy in wetland invasive species is weaker, phytotoxic compounds have been isolated in several Typha species (reviewed in Gallardo et al., 1998a, 1999, 2002), and experiments with root tissue extracts of invasive T. domingensis have revealed detrimental effects on the germination and growth of some species (e.g., Gallardo et al., 
1998b). Clearly, allelopathy is worthy of more rigorous biochemical and ecological research regarding invasiveness.

\section{F. Overview}

The above tests of five hypotheses involve only a few wetland species, notably Typha spp. The results for Typha provide evidence in support of four hypotheses, indicating that multiple traits can confer invasiveness. At the same time, a trait that enhances invasiveness in one species might not in another. For example, the production of copious seeds should increase invasiveness (and probably does for Impatiens grandulifera and Melaleuca quinquenervia), but one species that does not produce viable seed outside its native range is one of the worst invaders of wetlands in Europe and parts of North America (Polypogon cuspidatum), and the non-seed-producing Typha x glauca is also a widespread invader. Likewises, tall plants should shade out competitors, but annual grasses of short stature are among the most troublesome invaders in California wetlands (Parapholis incurva, Polypogon monspeliensis). Although no single trait explains all invasions, some traits provide multiple benefits to wetland invaders. A high proportion of aerenchyma (air tissue) simultaneously improves flood tolerance by increasing oxygen flow to roots, allows detached plants to float (disperse), and allows a plant to achieve high volume and height per biomass invested (efficient growth). Wetland plant traits and invasiveness do not follow a single or simple pattern.

\section{OPPORTUNITY-OPPORTUNIST MATCHES}

From the perspective of the potentially invaded community, no single species is invasive in all types of wetlands, although some species can invade multiple wetland types. So, with a variety of wetland species that have multiple "invader" attributes and a variety of potentially invaded wetland types that are sinks for a variety of materials and other disturbances, what generalities emerge? We agree with Sobrino et al. (2002) that invasions can be explained by considering the ecological requirements of the alien species and environmental factors. We argue that wetland opportunists are particularly invasive by virtue of having multiple attributes that match one or more of the opportunities afforded by disturbances that are common to landscape sinks.

Opportunities arise whenever natural or human-caused disturbances either introduce or free up resources (Davis et al., 2000). Increased flooding, sedimentation, and debris deposition are especially common in wetlands, and they combine multiple impacts that favor invaders. First, flooding can disadvantage resident vegetation, creating canopy gaps that allow high-lightrequiring invaders to establish (P. arundinacea; Lindig-Cisneros and Zedler, 2001, 2002a). Simultaneously inflowing water and sediments add or liberate nutrients from sediments, thereby enhancing growth of opportunistic plants (P. arundinacea; Kercher and Zedler, 2004). We propose several opportunity-opportunists matches (Table 2):

\section{A. Examples}

- Runoff is augmented when native habitats are replaced by agricultural fields or urban hardscapes. Species that readily disperse by water, and whose seeds, plant fragments, or whole plants establish well on bare ground, are well equipped to invade bare spaces along stream banks and floodplains (Tickner et al., 2001). When flooding occurs, sediments are both scoured and deposited, and flowing debris can create canopy gaps by ripping out some plants during transport while smothering others upon deposition. However formed, a canopy gap that is created by flooding can be quickly colonized by species with propagules that are carried to the site by the same floodwaters. Plants with floating propagules should be at an advantage, especially plant fragments that benefit from soaking in water (e.g., P. cuspidatum; Bimova et al., 2003) and mats that can continue growth while floating and establish rapidly upon settling (e.g., Alternanthera philoxeroides; Sainty et al., 1998). Flowing water and dispersal are integrally linked. In fact, a model by Campbell et al. (2002) suggests that river network characteristics can accurately predict plant dispersal rates.

- A flush of nutrients typically accompanies runoff from agricultural and urban land into wetlands. Species that can take up nutrients rapidly (e.g., T. domingensis in the Florida Everglades; Miao and Sklar, 1998) can benefit from such nutrient pulses. T. domingensis is able to take up and use nutrients by funneling them into growing tissues, while the native species it replaces $(\mathrm{Cla}$ dium jamaicense), if it responds at all, retains a limited quantity of nutrients in stem bases or belowground plant parts (Miao and Sklar, 1998). T. x glauca behaves similarly in Wisconsin (Woo and Zedler, 2002). Nutrient pulses are matched by nutrient slurpers. Flushes of phosphorus accompany peat fires, and species with high phosphorus uptake capability (e.g., T. domingensis) can respond rapidly to this disturbance (Smith and Newman, 2001).

- Sediments are exposed by floodwater scouring and sediment deposition. Species that establish readily and stabilize loose sediments can take advantage of this opportunity. Tamarix spp. are notable for this ability (Ellis et al., 2002), as is $P$. arundinacea, and both have been deliberately planted for the purpose of streambank erosion control. The former not only germinates well in open moist soil but also produces adventitious branches from buried roots and branches.

- Floodwaters accumulate in wetlands, and anoxia challenges all but the most flood-tolerant species, e.g., plants with aerenchyma or pressure ventilation. Plants with aerenchyma can also achieve high plant volume per biomass investment (i.e., "efficient growth"), potentially growing tall very rapidly (e.g., P. cuspidatum; 
TABLE 2

Opportunities in wetlands and the opportunists that appear to take advantage of them, based on the literature and personal observation

\begin{tabular}{|c|c|c|}
\hline Opportunity & Opportunist with & Examples of species \\
\hline Canopy gap & $\begin{array}{l}\text { Propagules that require high } \\
\text { light levels }\end{array}$ & $\begin{array}{l}\text { Melaleuca quinquenervia, } \\
\text { Phalaris arundinacea, } \\
\text { Impatiens glandulifera }\end{array}$ \\
\hline Canopy gap & $\begin{array}{l}\text { Rapid height growth, e.g., via } \\
\text { hollow stems }\end{array}$ & $\begin{array}{l}\text { Arundo donax, } \\
\text { Phalaris arundinacea, } \\
\text { Phragmites australis, } \\
\text { Polygonum cuspidatum }\end{array}$ \\
\hline $\begin{array}{l}\text { Flattened vegetation after } \\
\text { flooding }\end{array}$ & $\begin{array}{l}\text { Rapid upright branching to } \\
\text { recapture light }\end{array}$ & Phalaris arundinacea \\
\hline Nutrient pulse & Rapid nutrient uptake & $\begin{array}{l}\text { Schinus terebinthifolius, } \\
\text { Typha domingensis }\end{array}$ \\
\hline $\begin{array}{l}\text { Fresh sediment from scouring } \\
\text { or sediment deposition }\end{array}$ & Rapid anchoring of shoreline & $\begin{array}{l}\text { Tamarix spp., } \\
\quad \text { Phalaris arundinacea }\end{array}$ \\
\hline $\begin{array}{l}\text { Fresh sediment (flood } \\
\text { scouring or sediment } \\
\text { deposition) }\end{array}$ & $\begin{array}{l}\text { Hydrochory or viable floating } \\
\text { propagules }\end{array}$ & Polygonum cuspidatum \\
\hline Unvegetated mudflat & Inundation tolerance & $\begin{array}{l}\text { Spartina anglica, } \\
\quad \text { Spartina alterniflora }\end{array}$ \\
\hline Increased water depth & Aerenchyma & $\begin{array}{l}\text { Alternanthera philoxeroides, } \\
\text { Typha } x \text { glauca }\end{array}$ \\
\hline Increased water depth & $\begin{array}{l}\text { Adventitious roots and } \\
\text { tussock formation }\end{array}$ & Phalaris arundinacea \\
\hline $\begin{array}{l}\text { Warm water inflows in spring } \\
\text { and fall }\end{array}$ & Prolonged growing season & Phalaris arundinacea \\
\hline $\begin{array}{l}\text { Flooding, rapidly flowing } \\
\text { water }\end{array}$ & Dense rhizome mats that float & $\begin{array}{l}\text { Alternanthera philoxeroides, } \\
\text { Phalaris arundinacea, } \\
\text { Typha x glauca }\end{array}$ \\
\hline Altered hydroperiod & Broad ecological tolerance & Agrostis avenacea \\
\hline Increased salinity & Salt tolerance & Tamarix ramosissima \\
\hline Sea level rise & Salt and inundation tolerance & Spartina spp. \\
\hline $\begin{array}{l}\text { Decreased salinity } \\
\text { (low-salinity window) }\end{array}$ & $\begin{array}{l}\text { Rapid germination of seeds } \\
\text { plus salt-tolerant adults }\end{array}$ & $\begin{array}{l}\text { Parapholis incurva, } \\
\text { Polypogon monspeliensis, } \\
\text { Typha domingensis, } \\
\text { Typha orientalis }\end{array}$ \\
\hline
\end{tabular}

L. Seiger, personal communication). Roots that are rich in aerenchyma can extend further per unit biomass and take up nutrients over larger areas than roots without. While the value of belowground aerenchyma in moving oxygen to active tissues is well known (Jackson and Armstrong, 1999), efficient growth is not typically considered. Plants with aerenchymatous roots can make use of saturated soils, thereby solving the wateravailability constraints of hollow stems. Plants with aerenchyma match several opportunities afforded by wetlands that experience excess water inflows.

- Species that initiate growth earlier in spring and continue growth late in fall effectively extend the grow- ing season. This trait has been shown to be effective for an upland invader (Rhamnus cathartica) that outcompetes native shrubs without having a higher photosynthetic rate (Harrington et al., 1989). That is, the species can outgrow natives by photosynthesizing at a similar rate but for a longer time. $P$. arundinacea begins to sprout earlier than wet prairie and earlier than many sedge meadow plants in Wisconsin, and it is more capable of invading wet prairie than sedge meadow, presumably because more light is available (Maurer and Zedler, 2002; Lindig-Cisneros and Zedler, 2002b). The prolonged seasonal growth of $P$. arundinacea is well known; in fact, its persistent green color after 
native species have senesced allows it to be mapped from satellite imagery (Bernthal and Willis, 2004). Wetlands are made vulnerable to early-growing plants when snow on urban and agricultural lands begins to thaw. Dark-colored fields, asphalt streets, and rooftops produce early spring meltwater that flows downstream, where it warms the wetland soil next to drainage channels, accelerates thawing, and prompts early-spring growth of $P$. arundinacea (J. Zedler, personal observation). Late in fall, runoff likely continues longer from fields and towns, allowing such species a late-season advantage over species that senesce with the first cold weather. Thus, species with extended growing seasons are well matched to wetlands that receive agricultural and urban runoff.

- Open and standing water develops when runoff accumulates in wetlands or impoundments (dams) obstruct outflows. Species that produce tightly intertwined roots and rhizomes, especially if they are aerenchymatous, can allow plants to expand their distributions into water that would otherwise be too deep for emergent plants. Alternanthera philoxeroides extends outward from stream banks as floating mats (Sainty et al., 1998), while $P$. arundinacea forms tussocks that emerge above standing water. The propensity for the latter species to produce adventitious roots (Kercher and Zedler, In press) contributes to its ability to grow tussocks (J.Zedler, personal observation). Rising water is inhabitable if an invader can elevate itself by 20 to $30 \mathrm{~cm}$, which $P$. arundinacea readily accomplishes (Werner and Zedler, 2002). Increased flooding and stabilized water levels are well matched by opportunists that form floating mats or tussocks.

- Many structures (dams, levees, berms, culverts) placed in the landscape alter hydroperiods (frequency, depth, timing, and duration of high water). Species that are broadly tolerant of different hydroperiods (e.g., P. arundinacea; Miller and Zedler, 2003) should be well matched to sites that experience unusual hydroperiods due to such structures. A new invader, Agrostis avenacea, was first collected in San Diego County in 1987 in a vernal pool that had become larger and deeper when highway construction formed a berm that impounded water longer than natural vernal pools (Zedler and Black, In review). By 1998 A. avenacea had spread widely by "tumbleweed dispersal" into adjacent natural vernal pools that lacked significant human disturbance. This species grows taller and more robust than the region's native vernal pool grasses, most of which are diminutive. Since many opportunists are transported by vehicles, species that can take advantage of roadwaymodified wetlands should have both a dispersal and invasion advantage.

- Salinity regimes are altered when the boundary between fresh and saline waters shifts position. Where wetland soils become more saline, as where roads are salted to melt ice, or where secondary salinization occurs in arid regions due to the intensification of agriculture, diversion of water, and mining activities (Williams, 2001), an opportunity is provided for invasion by species with euryhaline propagules (i.e., seeds or fragments that are tolerant of a wide range of salinities). Typha angustifolia and Phragmites australis are frequent invaders of Midwestern road ditches, no doubt benefitting from vehicle dispersal and road construction disturbances, along with reduced cover by saltintolerant native vegetation (Galatowitsch et al., 1999). Where sea levels rise due to subsidence or global warming, invasive salt marsh species, e.g., Spartina spp., can be expected to move inland.

Where wetland soils become less saline, due to an unusually pulse of freshwater, species with stenohaline propagules can invade, and if the adult plants can tolerate salt they can persist. For example, T. domingensis invaded the San Diego River in 1980 during a prolonged period of freshwater inflows; the initial flood pulse was a natural event, but inflows were extended for months by reservoir releases that were intended to increase floodwater storage capacity upstream (Beare and Zedler, 1987). Subsequent experiments showed that seed germination and seedling stages were sensitive to salt, while rhizome-bearing plants could tolerate hypersaline conditions (Beare and Zedler, 1987). The same pattern held for Polypopogon monspeliensis in high salt marsh (Callaway and Zedler, 1998) following heavy rainfall events and T. orientalis invasions to the Canning Estuary in Western Australia following excavation of drainage ditches to accommodate urban runoff (Zedler et al., 1990).

\section{B. Overview}

The kinds of disturbances that occur in wetlands and the attributes of wetland invaders seem to be well matched and sufficiently different from those in uplands to warrant separate attention. The interaction of opportunity and opportunist often involves more than one aspect of either the site or the species. Some opportunities attract multiple opportunists, and some opportunists respond to multiple opportunities. Hence, predictions of which species will invade a wetland can only be general, based on the likelihood of bare space being made available, the simultaneous presence of an invader's propagules, and knowledge of any constraints on establishment, such as unusual salinity or hydroperiod (including drought) as well as any catalysts (e.g., nutrient pulses). Rarely would we know all of these factors for specific sites. But we do know that bare space does not remain bare for long in shallow-water wetlands, and that given time and chance dispersal of invasive plant propagules, invasive species are likely to establish. We also recognize that habitats subject to frequent mechanical disturbance, such as flood scouring, are readily colonized by "weedy" species, such as A. negundo and many species of Salix L., so it is not surprising that colonizers 
native to one region become invasive in other regions and continents.

Because some of the disturbances that create space also catalyze plant growth, wetlands are vulnerable to invasions. As demonstrated in tests of excess water, nutrients, and sediments on invasion by $P$. arundinacea, synergisms among flooding, nutrient influxes, and sediment influxes doubled the invasion rate over what was predictable by adding the individual treatment effects (Kercher and Zedler, 2004). Because stormwater runoff includes all three factors (flooding, nutrients, and sediments), it is understandable that wetlands downstream of agricultural lands or overfertilized lawns are susceptible to invasion and conversion to monotypic $P$. arundinacea. More multifactor experimental tests along these lines would lead to a more comprehensive understanding of wetland-invasive plants.

\section{OUTCOMES: HOW ARE WETLANDS ALTERED BY THEIR INVADERS?}

Invasive plants impact ecosystem functions both directly and indirectly. Direct impacts involve canopy height and other attributes of architecture, shifts from herbaceous to woody plants (or vice versa), increased productivity and litter, different litterbreakdown rates, altered nutrient regimes, and either increased or decreased flammability. Indirect impacts concern associations with microorganisms such as bacteria and mycorrhizae and larger invertebrate and vertebrate animals. The ecosystem functions mediated by plants that have received the most attention in the ecological literature involve biodiversity support, productivity, and nutrient cycling. Recent work on food web effects in marshes invaded by Phragmites australis is notable, however.

\section{A. Impacts on Habitat Structure}

Many invasives are unwanted because of the effects they have on habitat structure. In the U.S. Pacific Northwest, Spartina alterniflora changes tidal mudflats into salt marsh, thereby eliminating oyster habitat and bird-foraging habitat. In the Everglades, Melaleuca quinquenervia shifts the sawgrassdominated "river of grass" to a swamp, and in Puerto Rico, it shifts diverse forests to monotypes (Lugo, 2004). Unlike Tamarix spp., M. quinquenervia does not increase transpiration (Allen et al., 1997). In the arid southwestern U.S., Tamarix spp. replace desert and riparian species (willows and cottonwood; Stohlgren et al., 1998) along intermittent streams and washes, shifting vegetation from deciduous to evergreen and notably dewatering sites in the process by increasing transpiration rates. In addition, Tamarix spp. stabilize river banks and contribute to downcutting of river flow channels, resulting in narrow, deep channels that reduce the ability of rivers to meander and flood (Figure 3). The ultimate effect is to inhibit the natural regime of flood pulsing (Ellis et al., 2002). At the same time, the increased density of these flammable woody plants and litter increases fire frequency and intensity (Cox, 1999), and the invader lowers water tables to the disadvantage of native species. The magnitude of water loss due to invasive species is hard to estimate, although Le Maitre et al. (2000) calculated that South African catchments lose billions of cubic meters of water per year due to exotic invasive shrubs and trees.

P. australis has multiple impacts on marsh geomorphology by building up the marsh plain elevation (via increased sedimentation and organic matter production). Accretion of materials, including litter, can be twice as high as in marshes that this species replaces (Rooth et al., 2003) with rates that are 3 to $4 \mathrm{~mm}$ higher than uninvaded sites. In addition, P. australis is known for its ability to fill in small creeks (Lathrop et al., 2003). At Hog Island, New Jersey, a P. australis invasion of $20+$ years appears to have eliminated $8 \%$ of the length of first-order tidal creeks. When marsh elevation increases more rapidly than sea level rises, the marsh becomes drier; when creeks are filled in, access to the marsh by nekton is reduced. Together, the effect is to eliminate aquatic microhabitats that are important to juvenile mummichugs (Figure 4).

Species that greatly alter the physical structure of a site have high potential for shifting hydrological conditions and animal use. It is doubtful, however, if structural shifts and their secondary impacts are more dramatic in wetlands than in uplands.

\section{B. Impacts on Biodiversity}

Invasive wetland plants are generally assumed to reduce both plant and animal diversity, and our recent studies confirm this assumption (Werner and Zedler, 2002; Kercher et al., In press; Kercher and Zedler, 2004). As low species richness sometimes confers greater invasibility, the potential for positive feedbacks exists. An invader that causes a site to lose native species could become even more invasible.

Wetlands near Madison have the fewest species and lower quality species where $P$. arundinacea is present in sites with indicators of hydrological disturbance (e.g., drainage ditches that lower water tables or culverts that direct agricultural or urban runoff into the site) and where invasive species are present (Kercher et al., In press). Canopy architecture is also altered when native species are lost and invasives become dominant (A. Herr-Turoff, University of Wisconsin, unpublished data). Richburg et al. (2001) found that high salt concentrations and $P$. australis act independently to decrease species richness, evenness, and cover of native species in a fen community. Thus, invasive species degrade plant community integrity in multiple ways.

Evidence of plant invasion impacts on animal diversity is accumulating. Mensing et al. (1998) identified correlations between bird diversity and near-stream landscape condition and between fish composition and broader land use patterns. Blossey et al. (2001) reported reduced habitat in Lythrum salicaria stands for numerous insect and bird species that are habitat specialists (e.g., marsh wrens); likewise, Benoit and Askins (1999) found significantly fewer species of birds and 


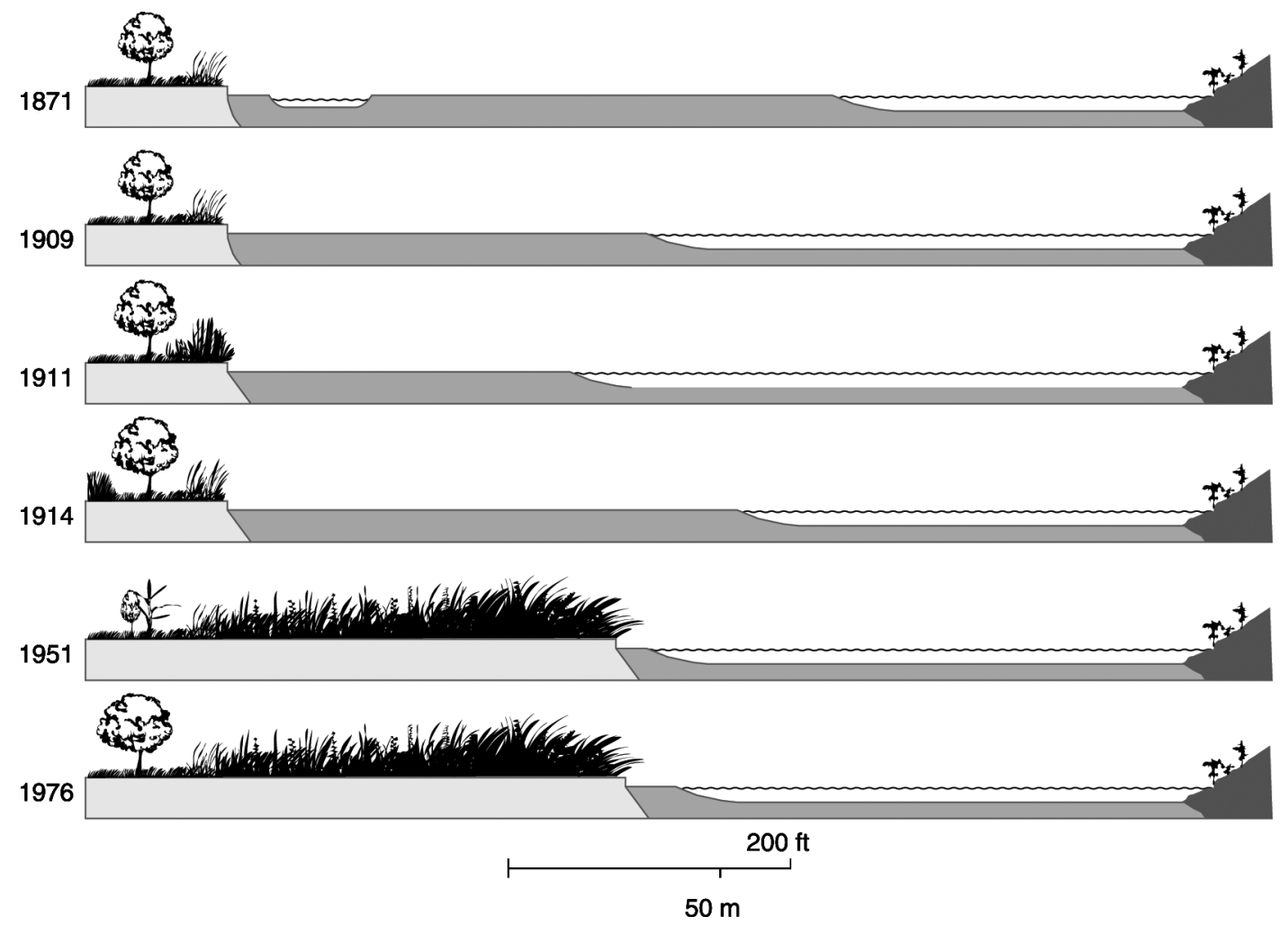

FIG. 3. Geomorphological impacts of tamarix on the Green River, Utah, as recorded from 1871 to 1976 . Note that the invader is credited with destabilizing the floodplain and river banks, such that the channel became narrower and deeper and no longer able to meander. Redrawn by K. Elliot from Graf (1978), with the author's permission.

state-listed species in phragmites-dominated wetlands than in native cordgrass marshes. However, E. Kirsch and M. Meier (USGS LaCrosse, WI, personal communication) did not find major differences in bird use of wet meadows dominated by natives versus those invaded by $P$. arundinacea, although some differences in invertebrate foods were evident.

Cox (1999) lists many impacts of Tamarix invasions on animal species, including reducing bird diversity and numbers, and reduced use by mule deer (Oidocoileus hemionus), beaver (Castor canadensis), and white-throated woodrats (Neotoma leucopus). Several studies have compared animal diversity in marshes invaded by $P$. australis with uninvaded Spartina alterniflora marshes. Fell et al. (1998) reported similar macroinvertebrates (snails, amphipods, and isopods) and use by the fish, Fundulus heteroclitus; Meyer et al. (2001) likewise found no differences in nekton abundance, biomass, and use in P. australis and native $S$. alterniflora marshes. Impacts on food webs, however, are detectable (see below). According to Able and Hagan (2000), the effects on F. heteroclitus are size specific; they found negative effects on larval and small juvenile fish but less or no effect on larger fish and on decapod crustaceans. Talley and Levin (2001) reported lower abundances of epifaunal gastropods (Succinea wilsoni and Stagnicola catascopium) and fewer arachnids, midges, tubuficid, and enchytraeid oligochaetes in phragmites marshes than in uninvaded marshes; however, phragmites stands supported more podurid insects, sabellid polychaetes, and peracarid crustaceans, and had greater habitat-wide taxon richness, as measured by rarefaction, than the uninvaded stands. Nevertheless, variations in salinity, age of stand, and seasonal effects may have influenced the patterns observed.

It is rarely clear how an invader eliminates individual native species. Two exceptions concern rare plant species. L. alatum had lower seed set in experiments with pure versus mixed pollen (Brown and Mitchell, 2001). In this case, pollen from L. salicaria interferes with the congener's reproduction. In the study of Parapholis incurva and Cordylanthus maritimus ssp. maritimus, root-attachment points on the invasive annual grass were too short-lived to support the endangered hemiparasite's haustoria (Fellows, 1999).

\section{Impacts on Productivity, Nutrient Cycling, and Microorganisms}

Invasive plants that differ from native species in biomass and productivity, tissue chemistry, plant morphology, or phenology can alter soil nutrient dynamics (Ehrenfeld, 2003). Ehrenfeld's recent review of upland and wetland plants provides tables comparing invasives versus natives for variables related to biomass, soil carbon, soil nitrogen, and other soil properties and fluxes (Ehrenfeld, 2003). Most of the species for which data are 


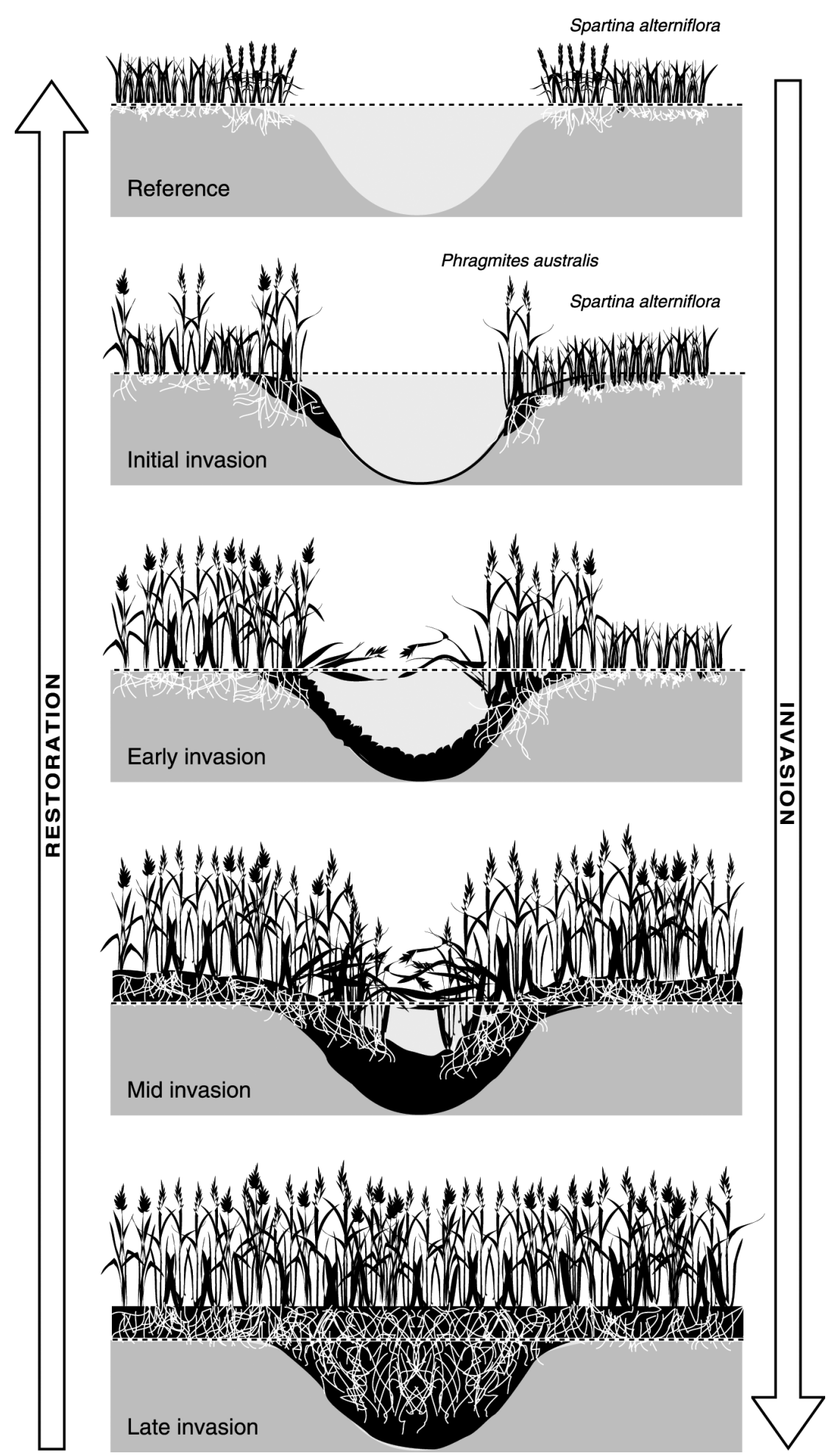

FIG. 4. P. australis changes marsh microtopography by filling in tidal creeks. Redrawn by K. Elliot from Able et al. (2003), with permission of the Estuarine Research Federation and approval from Ken Able.

available are terrestrial plants, but L. salicaria, P. australis, and Tamarix sp. appear repeatedly in the survey. While there are many studies that document effects of invasives, there are inconsistencies in pattern for different species and for the same species in different places (Ehrenfeld, 2003). Impacts on ecosystem function are can be site and species specific.

Much of the work on the effects of wetland invasive species on productivity, biomass, and nutrient cycling has been done in 
the northeastern U.S. In Windham and Meyerson's (2003) review, $P$. australis was described as increasing $\mathrm{N}$ standing crop, slowing whole-plant decomposition rates, and allocating more $\mathrm{N}$ to leaves, with less to stems, in comparison with the species it replaced. Effects on marsh $\mathrm{N}$ pools were highly variable and attributed to specific site effects. Ravit et al. (2003) found reduced diversity of phospholipid fatty acids, which in turn indicate lower activity of microbial populations in soils dominated by $P$. australis than S. alterniflora. Otto et al. (1999) evaluated microbial biomass and nutrient pools in stands of P. australis and L. salicaria that were invading Typha angustifolia in the Hudson River freshwater tidal marshes. P. australis had higher biomass than that of typha, and both $P$. australis and L. salicaria had higher $\mathrm{N}$ concentration in plant tissues, suggesting greater sequestration than typha. Soil nitrogen was reduced in L. salicaria and available inorganic $\mathrm{N}$ was higher in $P$. australis, changes that indicate important differences in $\mathrm{N}$ processing and retention, because the site has low N concentrations. Likewise, Templer et al. (1998) reported higher biomass for $P$. australis $(\sim 2 \times)$ and $L$. salicaria than for T. angustifolia, and $P$. australis had higher $\mathrm{N}$ content $(\sim 3 \times)$ than $T$. angustifolia. These authors conclude that the recent invaders have "subtle but ecologically significant effects on nutrient cycling," while Otto et al. (1999) concluded that they had no evidence that $P$. australis and $L$. salicaria changed nitrogen-removal capacity of this Hudson River wetland. Since T. angustifolia is also an invasive species, albeit an earlier arrival, the lack of major differences in nutrient-processing among these three species is understandable.

\section{Impacts on Food Webs}

Invasive species can affect food webs in multiple ways, by altering the quantity or quality of food, by changing food accessibility, or by changing vulnerability to predators. Perhaps the best-studied case concerns $P$. australis in the Northeastern U.S. There, Abel et al. (2003), Raichel et al. (2003), Osgood et al. (2003), and Fell et al. (2003) all found fewer juvenile fish on the marsh surface where P. australis was dominant compared to S. alterniflora, and Currin et al. (2003) suggested that fish consume $P$. australis somewhat in relation to its abundance in marshes, although benthic microalgae are more important sources of assimilated food. Both Raichel et al. (2003) and Osgood et al. (2003) found fewer invertebrates in P. phragmites versus $S$. alterniflora stands at some, but not all, times of the year. Jivoff and Abel (2003) found that Callinectes sapidus Rathbun (blue crab) preferentially fed on S. alterniflora compared to $P$. australis marsh surfaces. Fell et al. (2003) related higher numbers of Palaemonetes pugio Holthius (ghost shrimp) and lower numbers of Uca minax (LeConte; redjointed fiddler crab) to differences in marsh elevation where P. australis was dominant. The effect of $P$. australis on nesting by long-legged wading birds gave mixed results in a Delaware Bay study that compared the invaded marsh with upland habitats: four species nested equally in $P$. australis and upland, one species avoided $P$. australis, and one species confined itself to $P$. australis. One species had a higher reproductive rate in nests formed within $P$. australis. To summarize, the effects of $P$. australis on animals are not all negative. Impacts on invertebrates and food webs appear to be tightly linked with the effects that this invader has on marsh elevation and microtopography: by reducing hydroperiod and the area of tidal pools, habitat for aquatic animals is diminished (Figure 4).

Synthesizing the above, a reasonable scenario is that Phragmites invasion reduces topographic heterogeneity and raises the marsh plain elevation. Both of these "structural effects" would reduce the number and area of pools that would otherwise support benthic microalgae and invertebrates. The structural effect also involves a reduction in the length of small creeks, which would reduce the number and extent of access routes used by mummichog larvae to gain access to food reservoirs on the marsh surface. With fewer fish on the marsh surface, birds might have less food available. At the same time, primary productivity might increase, but if the biomass is less palatable to key consumers, it would not sustain the natural food web. One might expect a shift from a grazer-based toward a detritivore-based food web.

\section{ARE WETLANDS MORE VULNERABLE TO INVASIONS THAN UPLANDS?}

We have not considered all wetland invaders nor compared the proportions of upland and wetland plants that are invasive. We offer one calculation: The Global Invasive Species Database lists 33 plants among the 100 worst alien species; the fact that 8 of the 33 plants are wetland species seems disproportionate to the area of wetlands globally (4 to 6\% of the global land mass; Mitsch et al., 1994). That is, $24 \%$ of the worst plant invaders plague systems that cover $\leq 6 \%$ of the earth. We encourage a more thorough comparison of upland and wetland invasions.

We also encourage broader comparisons of the dominance forms of invasive and native plants in uplands versus wetlands. The dominance index of C. Frieswyk (University of Wisconsin, personal communication) provides a straightforward means of comparing species behavior across wetlands and larger spatial scales. For the Great Lakes region, species known to be invasive (Typha $x$ glauca, $P$. arundinacea, and P. australis) all exhibited the monotype form of dominance, while native dominants tended to serve as matrix species that coexisted with several other native species (Frieswyk et al., In review). Even if wetlands do not host a disproportionate share of the world's invaders, they seem to be particularly vulnerable to invasions that become monotypes (Figure 5 and Table 1).

The formation of monotypic stands occurs among clonal species, nonclonal perennials, and some annuals (e.g., I. glandulifera; Beerling and Perrins, 1993). The fact that wetlands are landscape sinks for water and nutrients helps to explain the widespread development of monotypes (Figure 6). As shown by Kercher and Zedler (2004), the strong synergism between flooding, nutrients, and sediments promoted the formation of monotypes of $P$. arundinacea, with the highest biomass of the invader and greatest loss of resident species occurring where flooding was continuous, nutrients were added at the highest level, and sediment addition was nutrient-rich topsoil. 


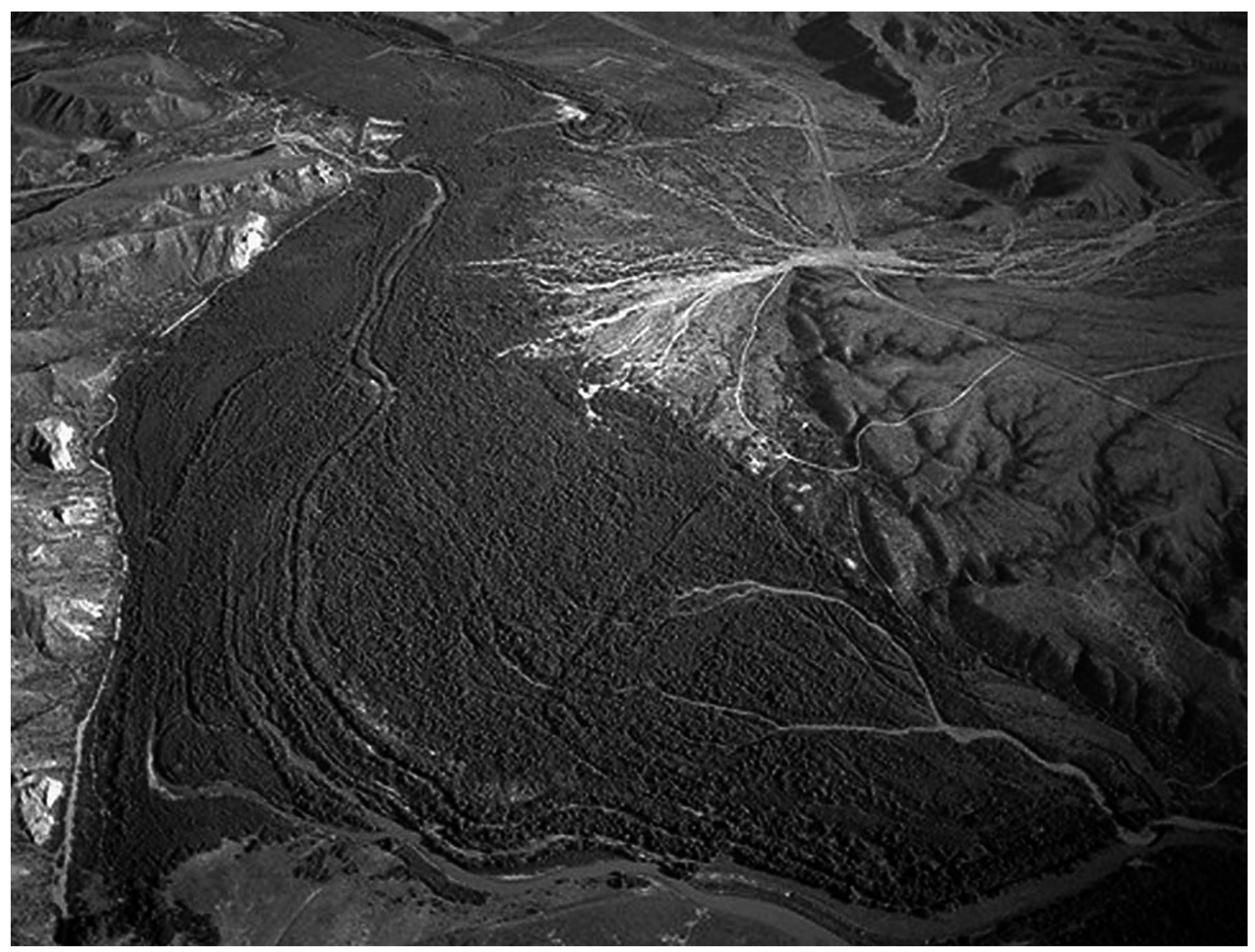

FIG. 5. Tamarix ramossissima monotype on the Rio Grande River, Texas. Photo taken in 1992 by Michael Collier, U.S. Geological Survey, courtesy of Environmental Defense (Mary Kelley).

Sedimentation is both a cause and an effect of wetland invasions. Where topographically complex wetlands are smothered in inflowing sediments, invasive plants find canopy gaps and bare soils to colonize (Werner and Zedler, 2002, Figure 1). Where sturdy invasive plants colonize streambanks, sediments accrete and change riparian geomorphology (Figures 4 and 5). The outcomes are similar-a simplification of topographic heterogeneity that is detrimental to the native community's ability to support species-rich vegetation. At the same time, sediments carry nutrients (especially phosphorus) that cause eutrophication and more rapid growth of many invasive plants.

Many invasive plants respond to the influx of water, nutrients, and sediments by increasing their growth rates. We argue that rapid height growth is achieved by many wetland plants via efficient growth; stems that are hollow and tissues that have high aerenchyma use little biomass. There are some constraints, however. Continuous water uptake is needed to compensate for high transpiration rates (caused by a low investment in biomass and lack of sclerophylly), and wetlands have ample water to replace evaporative losses. Also, hollow-stemmed plants cannot necessarily remain upright, as plants that invest little in structural material are vulnerable to windthrow, water damage, or trampling. Hollow stems should be able to remain upright, however, if they have a leaf or branch structure allows them to (1) intertwine (as in Alternanthera philoxeroides), (2) rest on their own standing dead biomass (as in Typha spp.), or (3) produce upright branches once the main stem has been flattened (as in $P$. arundinacea). Thus, we propose that plants with efficient growth via hollow stems and low investment in structural biomass have an advantage in wetlands.

A belowground attribute that likely contributes to monotype formation is the ability to produce dense root and rhizome mats. Those who attempt to excavate belowground biomass in Typhax glauca stands (e.g., I. Woo, personal communication) find little space for other species. Very likely the ability to form dense mats is related to the existence of aerenchyma, which both allows a high volume of belowground material and ensures that dense roots can remain functional by supplying oxygen.

Because wetlands function as sinks for water, nutrients, sediments, and other materials, and because many wetland invasive plants can take advantage of conditions, growing tall via efficient growth, wetlands appear to be more vulnerable than uplands to the formation of invasive monotypes (Figure 6). Elsewhere, we suggest that when a single disturbance, such as a stormwater pulse, simultaneously makes the wetland more invasible and the invader more invasive, the resident plant community will go 


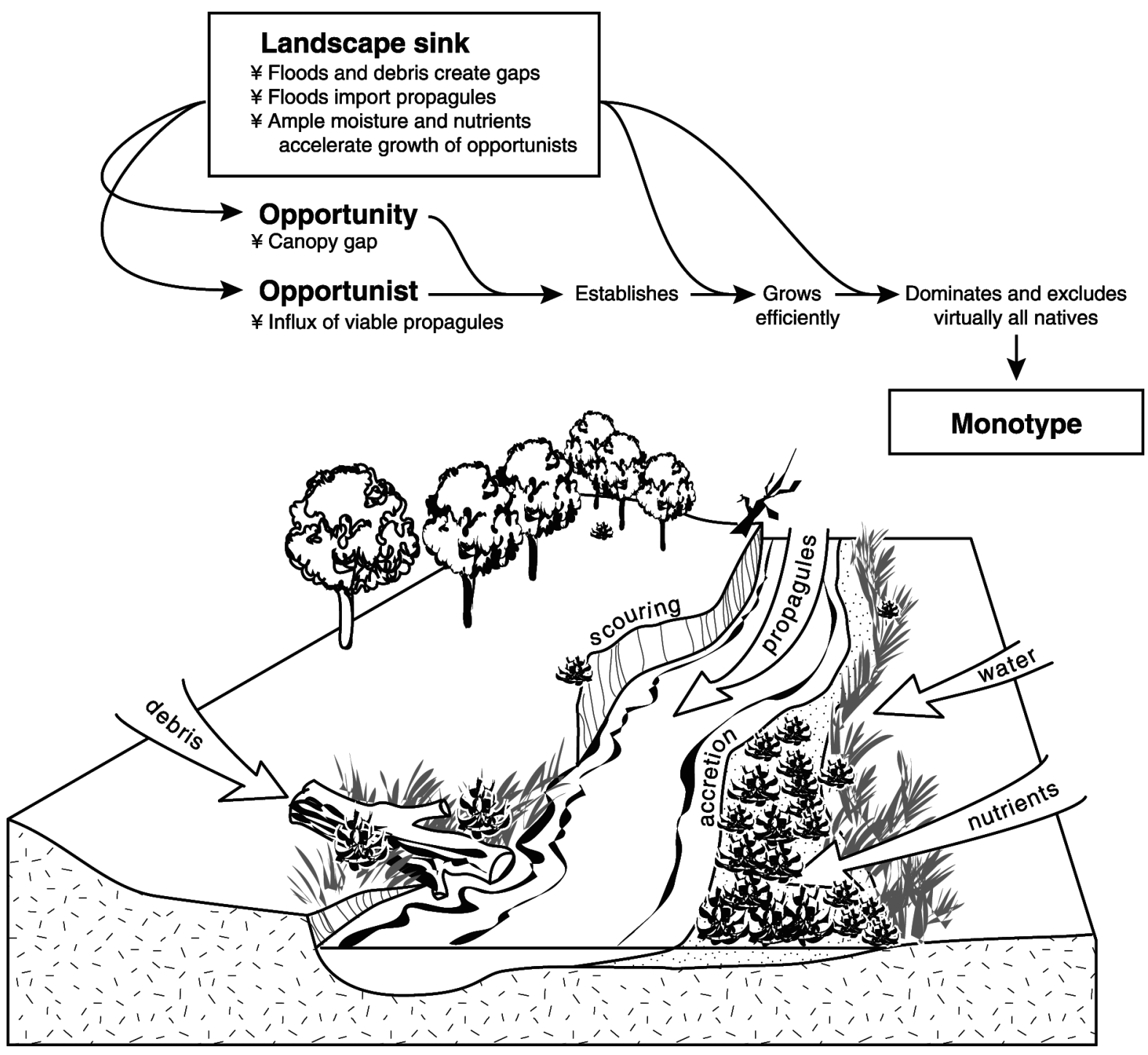

FIG. 6. Conceptual model showing how wetland position (as a landscape sink) has multiple influences on the formation of monotypes by wetland invasive plants: (1) Landscape sinks are subject to inflowing debris and flooding, which create canopy gaps that create opportunity for invasion, (2) floods bring in propagules (seeds, viable plant fragments, floating mats) of opportunistic species, and (3) flooding supplies water and nutrients that accelerate invasion and formation of monotypes. The opportunist is often one that initiates growth early in spring and grows tall quickly (e.g., P. arundinacea, which grows efficiently, producing high plant volume per unit biomass via hollow stems and aerenchyma). Illustrated by K. Elliot.

beyond accommodating the new species; it will likely shift toward a monotype (Maurer et al., 2003; Kercher et al., In press).

\section{CONCLUSIONS}

- Invasive plants in wetlands include grasses, graminoids, forbs, shrubs, and trees.

- Comparison of $\sim 20$ invasive wetland plants, including 8 that are among the 100 most invasive species on earth, failed to reveal any one attribute that explains their invasiveness.

- Wetland invaders share features with upland species (e.g., high productivity with nutrient influxes and abil- ity to extend the growing season), as well as features that are not common to most upland plants (highly efficient growth, i.e., high plant volume per unit biomass; tolerance to waterlogging; and water dispersal of propagules, including seeds, floatable plant parts, and vegetatively reproducing mats).

- Five hypotheses (enemy release, broader tolerance, efficient use, hybrid vigor, and allelopathy) have been tested, and each helps explain some wetland invasions. While no theory predicts the species that will invade a site or a region, several hypotheses have explanatory value a posteriori.

- Invasions in wetlands can be explained by simultaneously considering the nature of the opportunity and 
the availability of opportunists. Invasive plants establish where soils are bare (mudflats, riverbanks) and where disturbances create bare soil (erosion, sedimentation, debris deposition), all of which are associated with landscape sinks (wetlands). The species that take advantage of each opportunity depend on access (dispersal mode) and constraints (e.g., salt, native competitors). A posteriori, the opportunities seem well matched by the opportunists. Some opportunities attract multiple opportunists; some opportunists respond to multiple opportunities.

- Disturbances that involve multiple factors (e.g., stormwater inflows that involve flooding, nutrients, and sediments) likely increase invasion rates substantially, accelerating the rate of conversion from species-rich native vegetation to a monotype of an invasive species.

- Wetland invasive plants have substantial and persistent effects on habitat structure (including vegetating bare mudflats, stabilizing riverbanks, and reducing microtopographic heterogeneity), biodiversity (generally reducing numbers of species of plants and animals), and food web functioning (sometimes increasing food supplies, sometimes changing food quality). For the most part, outcomes are considered detrimental. Wetland that becomes dominated by invasive plants tend to support fewer native animal species, and ultimately more invasive animals will likely be attracted.

- We propose that wetlands are especially susceptible to invasions that become monotypes due to their landscape sink position, where disturbances, moisture, and nutrients all accumulate.

\section{ACKNOWLEDGMENTS}

Support from the National Science Foundation (DEB 0212005 to Zedler, Callaway, and Madon) for work on topographic heterogeneity is gratefully acknowledged. Work on P. arundinacea and Typha $x$ glauca was supported by the U.S. Environmental Protection Agency Science to Achieve Results (EPA-STAR) program-the former on grant R828010 from (R. Lathrop, K. Potter, and J. Zedler, coinvestigators) and the latter on the Great Lakes Environmental Indicators (GLEI) project, cooperative agreement EPA/R-82867501 (G. Niemi, principal investigator). Although the research described in this article has been funded wholly or in part by the USEPA, it has not been subjected to the Agency's required peer and policy review and therefore does not necessarily reflect the views of the Agency, and no official endorsement should be inferred.

\section{REFERENCES}

Able, K. W. and Hagan, S. M. 2000. Effects of common reed (Phragmites australis) invasion on marsh surface macrofauna: response of fishes and decapod crustaceans. Estuaries 23: 633-646.

Able, K. W., Hagan, S. M., and Brown, S. A. 2003. Mechanisms of marsh habitat alteration due to Phragmites: response of young-of-the-year mummichog
(Fundulus heteroclitus) to treatment for Phragmites removal. Estuaries 26: 484-494.

Ainouche, M. L., Baumel, A., Salmon, A., and Yannig, G. 2004. Hybridization, polyploidy and speciation in Spartina (Poaceae). New Phytol. 161: 165172.

Allen, L. H., Sinclair, T. R., and Bennett, J. J. 1997. Evapotranspiration of vegetation of Florida: perpetuated misconceptions versus mechanistic processes. Soil Crop Sci. Soc. Florida Proc. 56: 1-10.

Amon, J. P., Thompson, C. A., Carpenter, Q. J., and Miner, J. 2002. Temperate zone fens of the glaciated Midwestern USA. Wetlands 22: 301317.

Ayres, D. R., Garcia-Rossi, D., Davis, H. G., and Strong, D. R. 1999. Extent and degree of hybridization between exotic (Spartina alterniflora) and native ( $S$. foliosa) cordgrass (Poaceae) in California, USA determined by random amplified polymorphic DNA (RAPDs). Mol. Ecol. 8: 11791186.

Bailey, J. P., Child, L. E., and Wade, M. 1995. Assessment of the genetic variation and spread of British populations of Fallopia japonica and its hybrid Fallopia x bohemica. In: Plant Invasions: General Aspects and Special Problems, pp. 141-150, Pysek, P., Prach, K., Rejmanek, M., and Wade, M., Eds., SPB Academic Publishing, Amsterdam, Netherlands.

Bais, H. P., Vepachedu, R., Gilroy, S., Callaway, R. M., and Vivanco, J. M. 2003. Allelopathy and exotic plant invasion: from molecules and genes to species interactions. Science 301: 1377-1380.

Barrilleaux, T. C. and Grace, J. B. 2000. Growth and invasive potential of Sapium sebiferum (Euphorbiaceae) within the coastal prairie region: the effects of soil and moisture regime. Am. J. Botany 87: 1099-1106.

Bart, D. and Hartman, J. M. 2003. The role of large rhizome dispersal and low salinity windows in the establishment of common reed, Phragmites australis, in salt marshes: new links to human activities. Estuaries 26: 436-443.

Beare, P. A. and Zedler, J. B. 1987. Cattail invasion and persistence in a coastal salt marsh: the role of salinity. Estuaries 10: 165-170.

Bedford, B. L. and Godwin, K. S. 2003. Fens of the United States: distribution, characteristics and scientific connection versus legal isolation. Wetlands 23: 608-629.

Beerling, D. J. and Perrins, J. M. 1993. Impatiens glandulifera Royle (Impatiens roylei Walp.). J. Ecol. 81: 367-382.

Benoit, L. K. and Askins, R. A. 1999. Impact of the spread of Phragmites on the distribution of birds in Connecticut tidal marshes. Wetlands 19: 194208

Bernthal, T. W. 2003. Development of a Floristic Quality Assessment Methodology for Wisconsin. Wisconsin Department of Natural Resources, Pub-SS-986 2003, Madison, WI.

Bernthal, T. W. and Willis, K. G. 2004. Using Landsat Imagery to Map Invasive Reed Canary Grass (Phalaris arundinacea): A Landscape Level Wetland Monitoring Methodology. Wisconsin Department of Natural Resources, Madison, WI.

Bimova, K., Mandak, B., and Pysek, P. 2003. Experimental study of vegetative regeneration in four invasive Reynoutria taxa (Polygonaceae). Plant Ecol. 166: $1-11$.

Blossey, B., Schroeder, D., Hight, S. D., and Malecki, R. A. 1994a. Host specificity and environmental impact of the weevil Hylobius transversovittatus, a biological control agent of purple loosestrife (Lythrum salicaria). Weed Sci. 42: $128-133$.

Blossey, B., Schroeder, D., Hight, S. D., and Malecki, R. A. 1994b. Host specificity and environmental impact of two leaf beetles (Galerucella calmariensis and G. pusilla) for biological control of purple loosestrife (Lythrum salicaria). Weed Sci. 42: 134-140.

Blossey, B., Skinner, L. C., and Taylor, J. 2001. Impact and management of purple loosestrife (Lythrum salicaria) in North America. Biodiversity Conservation 10: 1787-1807.

Brinson, M. M. 1993. A Hydrogeomorphic Classification for Wetlands. Wetlands Research Program Technical Report WRP-DE-4. U.S. Army Corps of Engineers Waterways Experiment Station, Vicksburg, MS 
Brock, J. H., Child, L. E., de Waal, L. C., and Wade, M. 1995. The invasive nature of Fallopia japonica is enhanced by vegetative regeneration from stem tissues. In: Plant Invasions: General Aspects and Special Problems, pp. 131140, Pysek, P., Prach, K., Rejmanek, M., and Wade, M., Eds., SPB Academic Publishing, Amsterdam, Netherlands.

Brown, B. J. and Mitchell, R. J. 2001. Competition for pollination: effects of pollen of an invasive plant on seed set of a native congener. Oecologia 129: 43-49.

Caffrey, J. M. 2001. The management of giant hogweed in an Irish river catchment. J. Aquatic Plant Manage. 39: 28-33.

California State Coastal Conservancy (CSCC), San Francisco Estuary Invasive Spartina Project. http://www.spartina.org

Callaway, J. C. and Josselyn, M. 1992. The introduction and spread of smooth cordgrass (Spartina alterniflora) in South San Francisco Bay. Estuaries 15 218-226.

Callaway, J. C. and Zedler, J. B. 1998. Interactions between a salt marsh native perennial (Salicornia virginica) and an exotic annual (Polypogon monspeliensis) under varied salinity and hydroperiod. Wetlands Ecol. Manage. 5: 179-194.

Campbell, G. S., Blackwell, P. G., and Woodward, F. I. 2002. Can landscapescale characteristics be used to predict plant invasions along rivers? J. Biogeography 29: 535-543.

Chabbi, A., McKee, K. L., and Mendelssohn, I. A. 2000. Fate of oxygen losses from Typha domingensis (Typhaceae) and Cladium jamaicense (Cyperaceae) and consequences for root metabolism. Am. J. Botany 87: 1081-1090.

Conner, W. H., Mihalia, L., and Wolfe, J. 2002. Tree community structure and changes from 1987 to 1999 in three Louisiana and three South Carolina forested wetlands. Wetlands 22: 58-70.

Cox, G. W. 1999. Alien Species in North America and Hawaii: Impacts on Natural Ecosystems. Island Press, Washington, DC.

Currin, C. A., Wainright, S. C., Able, K. W., Weinstein, M. P., and Fuller, C. M. 2003. Determination of food web support and trophic position of the mummichog, Fundulus heteroclitus, in New Jersey smooth cordgrass (Spartina alterniflora), common reed (Phragmites australis), and restored salt marshes. Estuaries 26: 495-510.

Daehler, C. C., Denslow, J. S., Ansari, S., and Kuo, H.-C. 2004. A riskassessment system for screening out invasive pest plants from Hawaii and other Pacific islands. Conservation Biol. 18: 360-368.

Daehler, C. C. and Strong, D. R. 1997. Hybridization between introduced smooth cordgrass (Spartina alterniflora; Poaceae) and native California cordgrass (S. foliosa) in San Francisco Bay, California, USA. Am. J. Botany 84: 607611.

Dalrymple, G. H., Doren, R. F., O'Hare N. K., Norland, M. R., and Armentano, T. V. 2003. Plant colonization after complete and partial removal of disturbed soils for wetland restoration of former agricultural fields in Everglades National Park. Wetlands 23: 1015-1029.

Davis, M. A., Grime, J. P., and Thompson, K. 2000. Fluctuating resources in plant communities: a general theory of invisibility. J. Ecol. 88: 528-534.

Detenbeck, N. E., Galatowitsch, S. M., Atkinson, J., and Ball, H. 1999. Evaluating perturbations and developing restoration strategies for inland wetlands in the Great Lakes Basin. Wetlands 19: 789-820.

Drexler, J. Z. and Bedford, B. L. 2002. Pathways of nutrient loading and impacts on plant diversity in a New York peatland. Wetlands 22: 263 281.

Dudley, T. L. 2000. Arundo donax. In: Invasive Plants of California's Wildlands, pp. 53-58, Bossard, C. C., Randall, J. M., and Hoshovsky, M. C., Eds., University of California Press, Berkeley, CA. Also online at http://ceres.ca.gov/tadn/ecology_impacts/arundo_ww.html

Ehrenfeld, J. G. 2003. Effects of exotic plant invasions on soil nutrient cycling processes. Ecosystems 6: 503-523.

Ellis, L. M., Crawford, C. S., and Molles, M. C., Jr. 2002. The role of the flood pulse in ecosystem-level processes in southwestern riparian forests: a case study from the middle Rio Grande. In: Flood Pulsing in Wetlands: Restoring the Natural Hydrological Balance, pp. 51-107, Middleton, B. A., Ed., John Wiley \& Sons, NY.
Ellstrand, N. C. and Schierenbeck, K. A. 2000. Hybridization as a stimulus for the evolution of invasiveness in plants? Proc. Nat. Acad. Sci. USA 97: 7043-7050.

Farnsworth, E. J. and Meyerson, L. A. 2003. Comparative ecophysiology of four wetland plant species along a continuum of invasiveness. Wetlands $\mathbf{2 3}$ 750-762.

Fell, P. E., Warren, R. S., Light, J. K., Rawson, R. L., Jr., and Fairley, S. M. 2003. Comparison of fish and microinvertebrate use of Typha angustifolia, Phragmites australis, and treated Phragmites marshes along the Lower Connecticut River. Estuaries 26: 534-551.

Fell, P. E., Weissbach, S. P., Jones, D. A., Fallon, M. A., Zeppieri, J. A., Faison, E. K., Lennon, K. A., Newberry, K. J., and Reddington, L. K. 1998. Does invasion of oligohaline tidal marshes by reed grass, Phragmites australis (Cav.) Trin. ex Steud., affect the availability of prey resources for the mummichog, Fundulus heteroclitus L.? J. Exper. Marine Biol. Ecol. 222: 59-77.

Fellows, M. Q. 1999. Recovering a Rare and Endangered Hemiparasite: Interactions and Effects of Native and Exotic Hosts. Master's Thesis, San Diego State University, San Diego, CA.

Galatowitsch, S. M., Anderson, N. O., and Ascher, P. D. 1999. Invasiveness in wetland plants in temperate North America. Wetlands 19: 733-755.

Gallardo, M. T., Martin, B. B., and Martin, D. F. 1998a. An annotated bibliography of allelopathic properties of cattails, Typha spp. Florida Sci. 61: 52-58.

Gallardo, M. T., Martin, B. B., and Martin, D. F. 1998b. Inhibition of water fern Salvinia minima by cattail (Typha domingensis) extracts and by 2 chlorophenol and salicylaldehyde. J. Chem. Ecol. 24: 1483-1490.

Gallardo, M. T., Sawyers, W. G., and Martin, D. F. 1999. Concentrations of two phytotoxic materials in cattail extracts: 2-chlorophenol and salicylaldehyde. Florida Sci. 62: 164-171.

Gallardo Williams, M. T., Geiger, C. L., Pidala, J. A., and Martin, D. F. 2002. Essential fatty acids and phenolic acids from extracts and leachates of southern cattail (Typha domingensis P.). Phytochemistry 59: 305-308.

Gaskin, J. F. and Schaal, B. A. 2003. Molecular phylogenetic investigation of U.S. invasive Tamarix. Syst. Botany 28: 86-95.

Goodwin, B. J., McAllister, A. J., and Fahrig, L. 1999. Predicting invasiveness of plant species based on biological information. Conservation Biol. 13: 422 426.

Graf, W. L. 1978. Fluvial adjustments to the spread of Tamarisk in the Colorado Plateau region. Geol. Soc. Am. Bull. 9: 1491-1501.

Green, E. K. and Galatowisch, S. M. 2002. Effects of Phalaris arundinacea and nitrate-N addition on the establishment of wetland plant communities. J. Appl. Ecol. 39: 134-144.

Grevstad, F. S., Strong, D. R., Garcia Rossi, D., Switzer, R. W., and Wecker, M. S. 2003. Biological control of Spartina alterniflora in Willapa Bay, Washington using the planthopper Prokelisia marginata: agent specificity and early results. Biol. Control 27: 32-42.

Grotkopp, E., Rejmanek, M., and Rost, T. L. 2002. Toward a causal explanation of plant invasiveness: seedling growth and life-history strategies of 29 pine (Pinus) species. Am. Naturalist 159: 396-419.

Hagert, H. A. 2004. Competitive effect versus competitive response of invasive and native wetland plant species. Oecologia 139: 140-149.

Harrington, R. A., Brown, B. J., and Reich, P. B. 1989. Ecophysiology of exotic and native shrubs in southern Wisconsin (USA): I. Relationship of leaf characteristics, resource availability, and phenology to seasonal patterns of carbon gain. Oecologia 80: 356-367.

Hedge, P., Kriwoken, L. K., and Patten, K. 2003. A review of Spartina management in Washington State, US. J. Aquatic Plant Manage. 41: 82-90.

Howald, A. 2000. Lepidium latifolium. In: Invasive Plants of California's Wildlands, Bossard, C. C., Randall, J. M., and Hoshovsky M. C., Eds., University of California Press, Berkeley, CA. Online at http://ucce.ucdavis.edu/datastore/datareport.cfm?reportnumber $=42$

Jackson, M. B. and Armstrong, W. 1999. Formation of aerenchyma and the processes of plant ventilation in relation to soil flooding and submergence. Plant Biol. 1: 274-287. 
Jivoff, P. R. and Able, K. W. 2003. Blue Crab, Callinectes sapidus, response to the invasive common reed, Phragmites australis: abundance, size, sex ratio, and molting frequency. Estuaries 26: 587-595.

Kercher, S. M., Carpenter, Q. J., and Zedler, J. B. In press. Interrelationships of Hydrologic Disturbance, Reed Canary Grass (Phalaris arundinacea L.), and Native Plants in Wisconsin Wet Meadows. Natural Areas $J$.

Kercher, S. M. and Zedler, J. B. In press. Flood tolerance in wetland angiosperms: a comparison of native and invasive species. Aquatic Botany.

Kercher, S. M. and Zedler, J. B. 2004. Multiple disturbances accelerate invasion of reed canary grass (Phalaris arundinacea L.) in a mesocosm study. Oecologia 138: 455-464.

Kittelson, P. M. and Boyd, M. J. 1997. Mechanisms of expansion for an introduced species of cordgrass, Spartina densiflora, in Humboldt Bay, California. Estuaries 20: 770-778.

Klironomos, J. N. 2002. Feedback with soil biota contributes to plant rarity and invasiveness in communities. Nature 417: 67-70.

Koerselman, W. and Verhoeven, J. 1995. Eutrophication of fen ecosystems: external and internal nutrient sources and restoration strategies. In: Restoration of Temperate Wetlands, pp. 73-90, Wheeler, B. D., Shaw, S. C., Fojt, W. J., and Robertson, R. A., Eds., John Wiley \& Sons, Chichester, UK.

Kuhn, N. and Zedler, J. B. 1997. Differential effects of salinity and soil saturation on native and exotic plants of a coastal salt marsh. Estuaries 20: 391403.

La Foundation Total. 2004. Global Invasive Species Database, One hundred of the world's worst invasive alien species. http://www.lssg.org/database/ species/search.asp?st=100ss\&fr $=1 \&$ sts $=$

Langeland, K. A. and Craddock Burks, K., Eds. 2000. Identification and Biology of Non-native Plants in Florida's Natural Areas. IFAS Publication, University of Florida, Gainesville, FL. Online at http://plants.ifas.ufl.edu/identif. htma

Larkin, D., Vivian-Smith, G., and Zedler, J. B. In press. Topographic heterogeneity theory and applications to ecological restoration. In: Foundations of Restoration Ecology, Falk, D., Palmer, M., and Zedler J. B., Eds., Island Press, Washington, DC.

Lathrop, R. G., Windham, L., and Montesano, P. 2003. Does Phragmites expansion alter the structure and function of marsh landscapes? Patterns and processes revisited. Estuaries 26: 423-435.

Le Maitre, D. C., Versfeld, D. B., and Chapman, R. A. 2000. The impact of invading alien plants on surface water resources in South Africa: a preliminary assessment. Water South Africa 26: 397-408.

Lee, R. W. 2003. Physiological adaptations of the invasive cordgrass Spartina anglica to reducing sediments: rhizome metabolic gas fluxes and enhanced $\mathrm{O}_{2}$ and $\mathrm{H}_{2} \mathrm{~S}$ transport. Marine Biol. 143: 9-15.

Lempe, J., Stevens, K. J., and Peterson, R. L. 2001. Shoot responses of six Lythraceae species to flooding. Plant Biol. 3: 186-193.

Lesica, P. and Miles, S. 2001. Tamarisk growth at the northern margin of its naturalized range in Montana, USA. Wetlands 21: 240-246.

Levine, J. M., Vila, M., D’Antonio, C. M., Dukes, J. S., Grigulis, K., and Lavorel, S. 2003. Mechanisms underlying the impacts of exotic plant invasions. Proc. Roy. Soc. London Series B-Biol. Sci. 270 (1517): 775781.

Li, Y. and Norland, M. 2001. The role of soil fertility in invsion of Brazilian pepper (Schinus terebinthifolisus) in Everglades National Park, Florida. Soil Sci. 166: 400-405.

Lindgren, C. J. 2003. A brief history of Purple Loosestrife, Lythrum salicaria, in Manitoba and its status in 2001. Canadian Field-Naturalist 117: 100109.

Lindig-Cisneros, R. A. and Zedler, J. B. 2001. Effect of light on Phalaris arundinacea L. germination. Plant Ecol. 155: 75-78.

Lindig-Cisneros, R. and Zedler, J. B. 2002a. Relationships between canopy complexity and germination microsites for Phalaris arundinacea L. Oecologia 133: $159-167$.

Lindig-Cisneros, R. and Zedler, J. B. 2002b. Phalaris arundinacea L. seedling establishment: effects of canopy complexity in fen, mesocosm and restoration experiments. Can. J. Botany 80: 617-624.
Lopez, R. D. and Fennessy, M. S. 2002. Testing the floristic quality assessment index as an indicator of wetland condition. Ecol. Appl. 12: 487-497.

Lugo, A. 2004. The outcome of alien tree invasions in Puerto Rico. Frontiers Ecol. Environ. 2: 265-273.

Lynch, E. A. and Saltonstall, K. 2002. Paleoecological and genetic analyses provide evidence for recent colonization of native Phragmites australis populations in a Lake Superior wetland. Wetlands 22: 637-646.

Marigo, G. and Pautou, G. 1998. Phenology, growth and ecophysiological characteristics of Fallopia sachalinensis. J. Vegetation Sci. 9: 379-386.

Matthews, J. W. 2003. Assessment of the floristic quality index for use in Illinois, USA, wetlands. Natural Areas J. 23: 53-60.

Maurer, D. A., Lindig-Cisneros, R., Werner, K. M., Kercher, S., Miller, R., and Zedler, J. B. 2003. The replacement of wetland vegetation by Phalaris arundinacea (reed canary grass). Ecol. Restoration 21: 116119.

Maurer, D. A. and Zedler, J. B. 2002. Differential invasion of a wetland grass explained by tests of nutrients and light availability on establishment and vegetative growth. Oecologia 131: 279-288.

Mensing, D. M., Galatowitsch, S. M., and Tester, J. R. 1998. Anthropogenic effects on the biodiversity of riparian wetlands of a northern temperate landscape. J. Environ. Manage. 53: 349-377.

Meyer, D. L., Johnson, J. M., and Gill, J. W. 2001. Comparison of nekton use of Phragmites australis and Spartina alterniflora marshes in the Chesapeake Bay, USA. Marine Ecol. Prog. Series 209: 71-84.

Miao, S. L. and Sklar, F. H. 1998. Biomass and nutrient allocation of sawgrass and cattail along a nutrient gradient in the Florida Everglades. Wetlands Ecol. Manage. 5: 245-263.

Middleton, B. 1999. Wetland Restoration: Flood Pulsing and Disturbance Dynamics. J. Wiley \& Sons, NY.

Miller, R. C. and Zedler, J. B. 2003. Responses of native and invasive wetland plants to hydroperiod and water depth. Plant Ecol. 167: 57-69.

Mitchell, C. E. and Power, A. G. 2003. Release of invasive plants from fungal and viral pathogens. Nature 421: 625-627.

Mitsch, W. J., Mitsch, R. H., and Turner, R. E. 1994. Wetlands of the Old and New Worlds: ecology and management. In: Global Wetlands: Old World and New, pp. 3-56, Mitsch, W. J., Ed., Elsevier Science B.V., Amsterdam, NL.

Morris, L. L., Walck, J. L., and Hidayati, S. N. 2002. Growth and reproduction of the invasive Ligustrum sinense and native Forestiera ligustrina (Oleaceae): implications for the invasion and persistence of a nonnative shrub. Int. J. Plant Sci. 163: 1001-1010.

Mushet, D. M., Euliss, N. H., and Shaffer, T. L. 2002. Floristic quality assessment of one natural and three restored wetland complexes in North Dakota, USA. Wetlands 22: 126-138.

Newman, S., Grace, J. B., and Koebel, J. W. 1996. Effects of nutrients and hydroperiod on Typha, Cladium and Eleocharis: implications for everglades restoration. Ecol. Appl. 6: 774-783.

Noe, G. B. and Zedler, J. B. 2001. Variable precipitation limits the germination of upper intertidal marsh plants in southern California. Estuaries 24: 30-40.

Nyvall, R. F. and Hu, A. 1997. Laboratory evaluation of indigenous North American fungi for biological control of purple loosestrife. Biol. Control 8: $37-$ 42.

Olde Venterink, H., Davidsson, T. E., Kiehl, K., and Leonardson, L. 2002. Impact of drying and re-wetting on N, P and K dynamics in a wetland soil. Plant Soil 243: 119-130.

Osgood, D. T., Yozzo, D. J., Chambers, R. M., Jacobson, D., Hoffman, T., and Wnek, J. 2003. Tidal hydrology and habitat utilization by resident nekton in Phragmites and non-Phragmites marshes. Estuaries 26: 522533 .

Otto, S., Groffman, P. M., Findlay, S. E. G., and Arreola, A. E. 1999. Invasive plant species and microbial processes in a tidal freshwater marsh. J. Environ. Quality 28: 1252-1257.

Paveglio, F. L. and Kilbride, K. M. 2000. Response of vegetation to control of reed canarygrass in seasonally managed wetlands of southwestern Washington. Wildlife Soc. Bull. 28: 730-740. 
Prieur-Richard, A. H. and Lavorel, S. 2000. Invasions: the perspective of diverse plant communities. Austral. Ecol. 25: 1-7.

Pysek, P., Brock, J. H., Bimova, K., Mandak, B., Jarosik, V., Koukolikova, I., Pergl, J., and Stepanel, J. 2003. Vegetative regeneration in invasive Reynoutria (Polygonaceae) taxa: the determinant of invasibility at the genotype level. Am. J. Botany 90: 1487-1495.

Raichel, D. L., Able, K. W., and Hartman, J. M. 2003. The influence of Phragmites (common reed) on the distribution, abundance, and potential prey of a resident marsh fish in the Hackensack Meadowlands, New Jersey. Estuaries 26: $511-521$.

Ravit, B., Ehrenfeld, J. G., and Haggblom, M. M. 2003. A comparison of sediment microbial communities associated with Phragmites australis and Spartina alterniflora in two brackish wetlands of New Jersey. Estuaries 26: 465-474.

Rea, N. 1998. Biological control: premises, ecological input and Mimosa pigra in the wetlands of Australia's Top End. Wetlands Ecol. Manage. 5: 227242.

Rejmanek, M. 2000. Invasive plants: approaches and predictions. Austral Ecol. 25: 497-506.

Richardson, D. M., Pysek, P., Rejmanek, M., Barbour, M. G., Panetta, F. D., and West, C. J. 2000. Naturalization and invasion of alien plants: concepts and definitions. Diversity Distributions 6: 93-107.

Richburg, J. A., Patterson, W. A. III, and Lowenstein, F. 2001. Effects of road salt and Phragmites australis invasion on the vegetation of a western Massachusetts calcareous lake-basin fen. Wetlands 21: 247-255.

Rogers, W. E. and Siemann, E. 2003. Effects of simulated herbivory and resources on Chinese tallow tree (Sapium sebiferum, Euphorbiaceae) invasion of native coastal prairie. Am. J. Botany 90: 243-249.

Rooth, J., Stevenson, C., and Cornwell, J. C. 2003. Increased sediment accretion rates following invasion by Phragmites australis: the role of litter. Estuaries 26: $475-483$.

Sainty, G., McCorkelle, G., and Julien, M. 1998. Control and spread of alligator weed Alternanthera philoxeroides (Mart.) Giseb., in Australia: lessons for other regions. Wetlands Ecol. Manage. 5: 195-201.

Saltonstall, K. 2002. Cryptic invasion by a non-native genotype of the common reed, Phragmites australis, into North America. Proc. Nat. Acad. Sci. USA 99: 2445-2449.

Schaal, B. A., Gaskin, J. F., and Caicedo, A. L. 2003. Phylogeography, haplotype trees, and invasive plant species. J. Heredity 94: 197204.

Seiger, L. A. and Merchant, H. C. 1997. Mechanical control of Japanese knotweed (Fallopia japonica [Houtt.] Ronse Decraene): effects of cutting regime on rhizomatous reserves. Natural Areas J. 17: 341-345.

Sher, A. A., Marshall, D. L., and Taylor, J. P. 2002. Establishment patterns of native Populus and Salix in the presence of invasive nonnative Tamarix. Ecol. Appl. 12: 760-772.

Siemann, E. and Rogers, W. E. 2001. Genetic differences in growth of an invasive tree species. Ecol. Lett. 4: 514-518.

Simberloff, D., Schmitz, D. D., and Brown, T. C. 1997. Strangers in Paradise: Impact and Management of Nonindigenous Species in Florida. Island Press, Washington, DC.

Smith, R. G. B. and Brock, M. A. 1995. Coexistence of Juncus articulatus L. and Glyceria australis CE Hubb in a temporary shallow wetland in Australia. Hydrobiologia 340: 147-151.

Smith, S. M. and Newman, S. 2001. Growth of southern cattail (Typha domingensis pers.) seedlings in response to fire-related soil transformations in the Northern Florida Everglades. Wetlands 21: 363-369.

Sobrino, E., Sanz-Elorza, M., Dana, E. D., and Gonzalez-Moreno, A. 2002. Invasibility of a coastal strip in NE Spain by alien plants. J. Vegetation Sci. 13: $585-594$.

Soukup, A., Votrubova, O., and Cizkova, H. 2000. Internal segmentation of rhizomes of Phragmites australis: protection of the internal aeration system against being flooded. New Phytologist 145: 71-75.

Spicher, D. and Josselyn, M. 1985. Spartina (Gramineae) in northern California: distribution and taxonomic notes. Madroño 32: 158-167.
Stevens, L. E. 1989. The status of ecological research on tamarisk (Tamaricaceae: Tamarix ramosissima) in Arizona. In: Tamarisk Control in Southwestern United States, pp. 99-105, Kunzman, M. R., Johnson, R. R., and Bennett, P. S., Eds., Special Report Number 9, Cooperative National Park Resources Study Unit, Tucson, AZ.

Stohlgren, T. J., Bull, K. A., Otsuki, Y., Villa, C. A., and Lee, M. 1998. Riparian zones as havens for exotic plant species in the central grasslands. Plant Ecol. 138: $113-125$.

Stratton, L. C. and Goldstein, G. 2001. Carbon uptake, growth and resource-use efficiency in one invasive and six native Hawaiian dry forest tree species. Tree Physiol. 21: 1327-1334.

Sukopp, H. and Starfinger, U. 1995. Reynoujtria sachalinensis in Europe and in the Far East: a comparison of the species ecology in its native and adventive distribution range. In: Plant Invasions: General Aspects and Special Problems, pp. 151-160, Pysek, P., Prach, K., Rejmanek, M., and Wade, M., Eds., SPB Academic Publishing, Amsterdam, Netherlands.

Tabacchi, E. and Planty-Tabacchi, A. M. 2003. Recent changes in riparian vegetation: possible consequences on dead wood processing along rivers. River Res. Appl. 19: 251-263.

Talley, T. S. and Levin, L. A. 2001. Modification of sediments and macrofauna by an invasive marsh plant. Biol. Invasions 3: 51-68.

Templer, P., Findlay, S., and Wigand, C. 1998. Sediment chemistry associated with native and non-native emergent macrophytes of a Hudson River marsh ecosystem. Wetlands 18: 70-78.

Thompson, D. Q., Stuckey, R. L., and Thompson, E. B. 1987. Spread, impact, and control of purple loosestrife (Lythrum salicaria) in North American wetlands. In: Northern Prairie Wildlife Research Center Home Page, pp. 1-55. U.S. Fish and Wildlife Service. Jamestown, ND. Online at http://www.npwrc.usgs.gov/resource/1999/loosstrf/loosstrf.htm (Version 04JUN99).

Thompson, J. D. 1991. The biology of an invasive plant—what makes Spartina anglica so successful? BioScience 41: 393-401.

Tickner, D. P., Angold, P. G., Gurnell, A. M., and Mountford, J. O. 2001. Riparian plant invasions: hydrogeomorphological control and ecological impacts. Progress in Physical Geography 25: 22-52.

Toney, J. C., Rice, P. M., and Forcella, F. 1998. Exotic plant records in the northwest United States 1950-1996: an ecological assessment. Northwest Sci. 72: 198-213.

Turner, C. E., Center, T. D., Burrows, D. W., and Buckingham, G. R. 1998. Ecology and management of Melalecuca quinquenervia, and inavder of wetlands in Florida, USA. Wetlands Ecol. Manage. 5: 165178.

USDA, NRCS. 2004. The PLANTS Database, Version 3.5, National Plant Data Center, Baton Rouge, LA. Online at http://plants.usda.gov.

Uveges, J. L., Corbett, A. L., and Mal, T. K. 2002. Effects of lead contamination on the growth of Lythrum salicaria (purple loosestrife). Environ. Poll. 120 319-323.

Voegtlin, D. J. 1995. Potential of Myzus lythri (Homoptera: Aphididae) to influence growth and development of Lythrum salicaria (Myrtiflorae: Lythraceae) Environ. Entomol. 24: 724-729.

Weber, E. 2000. Switzerland and the invasive plant species issue. Botanica Helvetica 110: 11-24.

Werner, K. J. and Zedler, J. B. 2002. How sedge meadow soils, microtopography, and vegetation respond to sedimentation. Wetlands 22: 451466.

Williams, W. D. 2001. Salinization: unplumbed salt in a parched landscape Water Sci. Technol. 43: 85-91.

Willis, A. J. and Thomas, M. B. 1999. Is the increased vigour of invasive weeds explained by a trade-off between growth and herbivore resistance? Oecologia 120: $632-640$.

Windham, L. and Meyerson, L. A. 2003. Effects of common reed (Phragmites australis) expansions on nitrogen dynamics of tidal marshes of the northeastern US. Estuaries 26: 452-464.

Woo, I. and Zedler, J. B. 2002. Can nutrients alone shift a sedge meadow towards the invasive Typha x glauca? Wetlands 22: 509-521. 
Zavaleta, E. 2000. The economic value of controlling an invasive shrub. AMBIO 29: 462-467.

Zedler, J. B., Paling, E., and McComb, A. 1990. Differential salinity responses help explain the replacement of native Juncus kraussii by Typha orientalis in Western Australian salt marshes. Austral. J. Ecol. 15: $57-$ 72 .
Zedler, J. B. and Rea, N. 1998. Introduction to the ecology and management of wetland plant invasions. Wetlands Ecol. Manage. 5: 161163.

Zedler, P. H. and Black, C. In review. Exotic plant invasions in an endemic-rich habitat: the spread of an introduced Australian grass, Agrostis avenacea J. F. Gmel. in California vernal pools. Austral. Ecol. 